\title{
Late Miocene to Pleistocene potassic volcanism in the Republic of Macedonia
}

\author{
Yotzo Yanev • Blazo Boev • Carlo Doglioni • \\ Fabrizio Innocenti • Piero Manetti • Zoltan Pecskay • \\ Sonia Tonarini • Massimo D'Orazio
}

Received: 5 December 2007 / Accepted: 27 March 2008

(C) Springer-Verlag 2008

\begin{abstract}
The potassic (K) to ultrapotassic (UK) volcanic rocks cropping out in the Vardar Zone of Macedonia and southern Serbia span in age from Late Miocene (6.57 Ma)
\end{abstract}

Editorial handling: J.G. Raith

\section{Y. Yanev}

Geological Institute, Bulgarian Academy of Sciences,

Acad. G. Boncev str., bl. 24,

1113 Sofia, Bulgaria

e-mail: yotzo@geology.bas.bg

B. Boev

University St Ciril and Metodii, Faculty of Mining and Geology,

Shtip, Republic of Macedonia

e-mail: blazo.boev@ugd.edu.mk

\section{Doglioni}

Università La Sapienza, Dipartimento di Scienze della Terra,

P.le A. Moro 5, 00184 Rome, Italy

e-mail: carlo.doglioni@uniroma1.it

\section{F. Innocenti $\cdot$ M. D'Orazio}

Università di Pisa, Dipartimento di Scienze della Terra,

Via S. Maria 53, 50126 Pisa, Italy

F. Innocenti

e-mail: innocen@dst.unipi.it

\section{D’Orazio}

e-mail: dorazio@dst.unipi.it

F. Innocenti $\cdot$ P. Manetti $\cdot$ S. Tonarini $(\bowtie)$

Istituto di Geoscienze e Georisorse, CNR,

Via G. Moruzzi 1, 56124 Pisa, Italy

e-mail: s.tonarini@igg.cnr.it

P. Manetti

e-mail:manetti@unifi.it

\section{Z. Pecskay}

ATOMKI, Hungarian Academy of Sciences,

4001 Debrecen, Hungary

e-mail: pecskay@namafia.atomki.hu to Pleistocene (1.47 Ma). The main identified outcrops are in the Kumanovo, Sveti Nikole, Shtip and Demir Kapia areas; the southernmost occurrences of these volcanic rocks are located in the large Kozuf Massif (Voras Massif in Greece) at the Macedonia-Greek border. Three distinct groups may be distinguished. The first group has a shoshonitic affinity and occurs in the Kozuf Massif (LMg$\mathrm{K}$ group); it includes shoshonites to rare rhyolites, with latites and trachytes being the most widespread products. The second group consists of potassic rocks ( $\mathrm{HMg}-\mathrm{K}$ group, $\mathrm{K}_{2} \mathrm{O} / \mathrm{Na}_{2} \mathrm{O}$ between 1.0 and 1.8) occurring in both southern Serbia (Cer and Slavujevci) and Macedonia (Djuristhe, near Sveti Nikole). The third group, present only in Macedonia, consists of ultrapotassic rocks (UK group, $\mathrm{K}_{2} \mathrm{O} / \mathrm{Na}_{2} \mathrm{O}>1.8, \mathrm{Mg} \#>71$ ) classified as UK shoshonites, UK latites and UK phonotephrites; overall, they show a "Roman Province type" affinity (Group III of Foley, Venturelli, Green, Toscani, Earth Sci Rev 24:81-134, 1987). Geochemically, the studied rocks exhibit strong enrichment in LILE, Th and $\mathrm{Pb}$, as well as relative depletion in $\mathrm{Ta}-\mathrm{Nb}$ and $\mathrm{Hf}$; such signatures are typical of magmas generated in convergent geotectonic settings. In the $\mathrm{HMg}-\mathrm{K}$ and $\mathrm{UK}$ rocks, $\mathrm{Sr}$ and $\mathrm{Nd}$ isotopic ratios vary from 0.70768 to 0.71040 , and 0.51243 to 0.512149 , respectively. The rocks of the $\mathrm{LMg}-\mathrm{K}$ group show relatively limited $\mathrm{Sr}$ and $\mathrm{Nd}$ isotope variations (0.7087-0.7093 and $0.51233-0.51229$ ), which correlate with a decrease in $\mathrm{MgO}$ and increase in $\mathrm{SiO}_{2}$ contents. The geochemical features of the $\mathrm{LMg}-\mathrm{K}$ volcanic rocks indicate that their evolution was mainly driven by fractional crystallization coupled with contamination by feldspar-rich crustal materials. In contrast, the $\mathrm{HMg}-\mathrm{K}$ and UK rocks have not been significantly modified by crustal contamination, and their geochemical features are considered to reflect lithospheric mantle heterogeneity acquired during the subduction of the 
Western Vardar Ocean and the Apulian plate. The metasomatizing agent was apparently more enriched in $\mathrm{Zr}$, Th, $\mathrm{Ta}$ and $\mathrm{Ce}$ than in fluid-mobile elements, such as $\mathrm{Pb}$ and Cs, suggesting that it was characterized by a high melt/fluid ratio. The potassic and ultrapotassic magmatic activity developed in response to the Pliocene-Pleistocene extension in the Vardar Zone, in turn related to the opposite propagation of extension in the Aegean and Pannonian basins (respectively SW and NE).

\section{Introduction}

Starting in the Jurassic-Cretaceous, the central and northeastern part of the Balkan Peninsula was affected by NEdirected subduction, with both SW (Hellenides-Dinarides) and NE (Balkans) migration of the conjugate orogenic fronts and intervening later extension (Doglioni et al. 1996). As a result of this complex geotectonic evolution, a calc-alkaline and shoshonitic volcanic arc developed in the Late Paleogene-Middle Miocene (Fig. 1; e.g., Pamić et al. 1998). Eruptive products form a NW-SE belt extending for over $1,600 \mathrm{~km}$ from southeastern Austria to northwest-

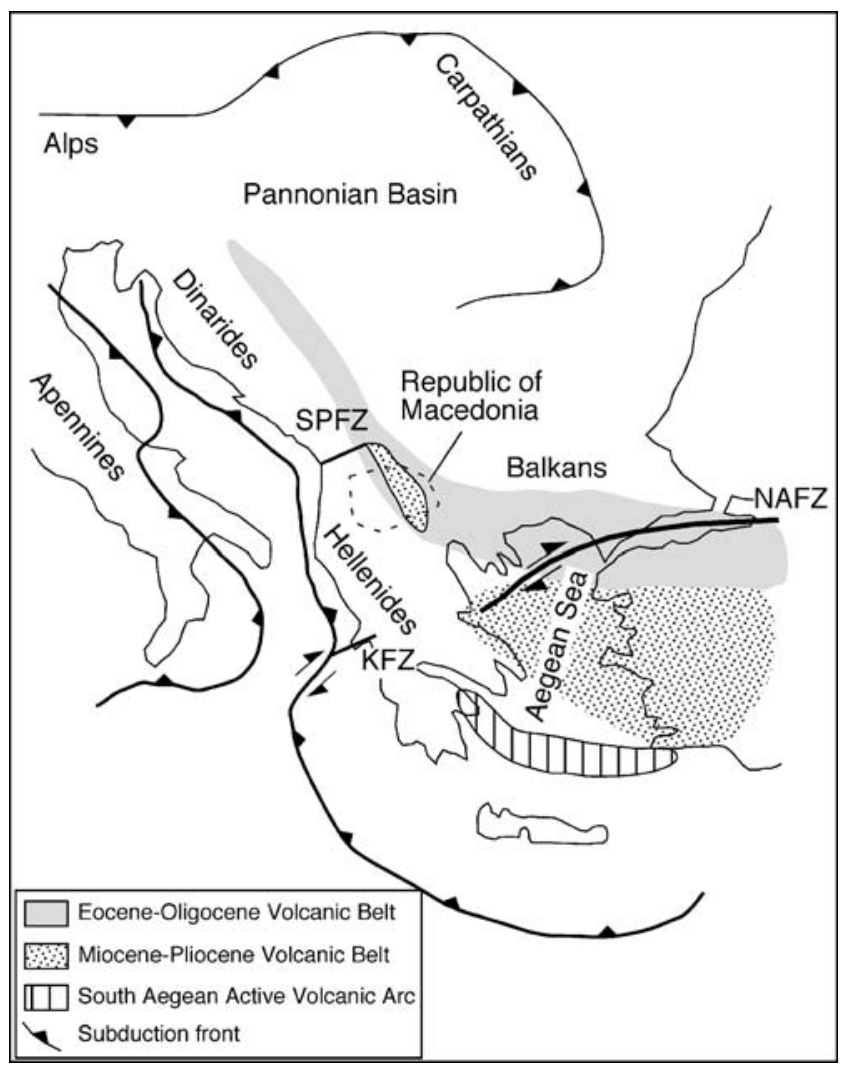

Fig. 1 Simplified tectonic map of the Eastern Mediterranean region (modified after Dumurdzanov et al. 2004) with the location of Eocene-Oligocene, Miocene-Pliocene and active volcanic belts. $S P F Z$ Scutari-Peć Fault Zone, KFZ Kefalonia Fault Zone, NAFZ North Anatolian Fault Zone ern Turkey, traversing the Balkan Peninsula (Harkovska et al. 1989; Kovács et al. 2007). The main phase of orogenic magmatism was locally followed by scattered potassic to ultrapotassic volcanism (Cvetković et al. 2004; 2007; Yanev 2003; Yanev et al. 2003; Agostini et al. 2007) that developed from Serbia to Turkey. From the Late Miocene to Pleistocene, in the region between southern Serbia and Macedonia, shoshonitic to ultrapotassic volcanism formed a discontinuous belt starting just south of the Scutari-Peć fault zone, regarded as the northern limit of the extensional area associated with the Hellenic subduction system (Boccaletti et al. 1974).

The ultrapotassic volcanism of southern Serbia and Macedonia has been the object of several recent studies mainly addressing its geochemical and petrological characteristics (Boev and Lepitkova 1991; Cvetković et al. 2004, 2007; Altherr et al. 2004; Prelević et al. 2001, 2005, 2007; Boev and Yanev 2001; Yanev et al. 2003). This paper describes the temporal and spatial evolution of the potassic and ultrapotassic rocks erupted since the Late Miocene to Pleistocene from the Scutari-Peć fault zone down to the southernmost part of Macedonia, to the volcanic KozufVoras Massif at the border between Macedonia and Greece. New geochronological, geochemical and isotopic data, along with literature data, are used to discuss the petrogenesis of these rocks in the context of the geodynamic evolution of the area.

\section{Geodynamic framework}

Southern Serbia and Macedonia are located at the core of the Dinarides orogen, where the oceanic sliver of the Vardar unit is sandwiched between the continental basement rocks of the upper Western European plate (Serbo-Macedonian metamorphic rocks) and the lower Apulia plate (Pelagonian unit, e.g., Carminati et al. 2004). The subduction record goes back to at least the Paleocene (Carminati et al. 2004), but evidence from the Cretaceous supports an earlier onset. Collision took place in the Paleocene-Eocene (Pamić et al. 1998). Southern Serbia and Macedonia are still in the hanging wall of an active subduction zone, although the present subduction rate along the eastern coast of the Adriatic Sea seems to be very slow (e.g., Battaglia et al. 2004). Therefore, the calcalkaline-shoshonitic magmatic rocks occurring in the study area are compatible with the aforementioned long history of subduction-collision. However, widespread extension, with the formation of NNW-trending grabens, affected the area starting in the Paleogene (Dumurdzanov et al. 2004); southern Serbia and Macedonia form an area in which the southern margin of the eastward-propagating Pannonian extension and the northwestward margin of the southwestward-propagating Aegean extension overlap in time and 
Fig. 2 Sketch map of Republic of Macedonia showing locations of the volcanic centers studied. In parentheses the $\mathrm{K}-\mathrm{Ar}$ ages (Ma) of volcanic rocks (this work and literature data)

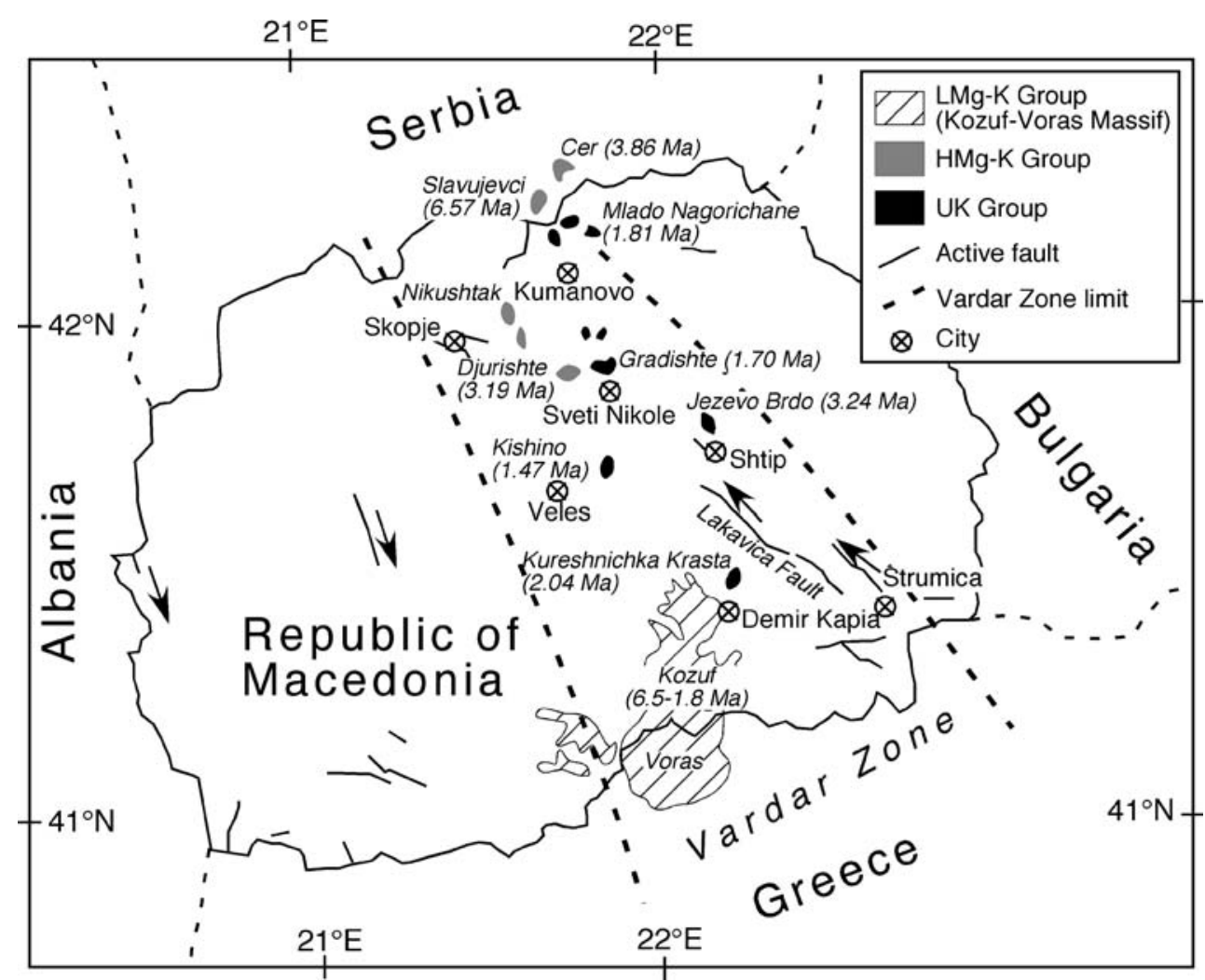

space. A number of Paleogene and Miocene to Pleistocene grabens, filled by coarse-grained siliciclastic sediments and volcanic rocks, accomplished the two independent and coexisting extensional settings. Due to its proximity, the

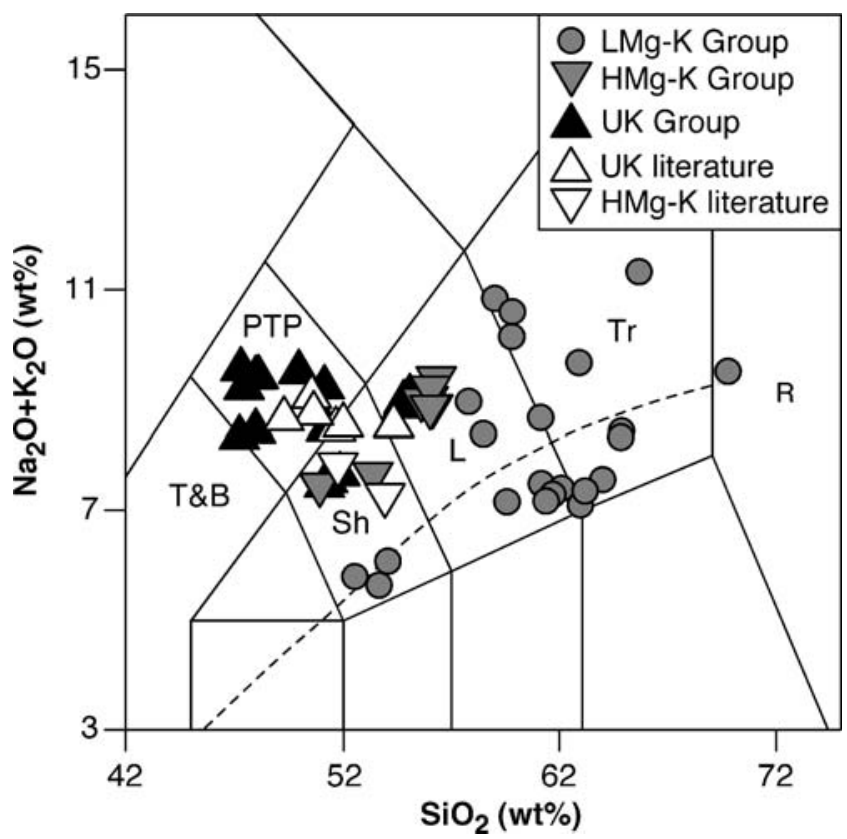

Fig. 3 Total alkali-silica classification diagram. $T \& B$ tephrite and basanite, PTP phonotephrite, $S h$ shoshonite, $L$ latite, $\operatorname{Tr}$ trachyte, $R$ rhyolite. The dashed line between alkaline and subalkaline rocks of Irvine and Baragar (1971) is also plotted. Literature data for this diagram and the following ones are from Altherr et al. (2004) and Cvetković et al. (2004) study area was possibly more affected by Aegean tectonics, as also suggested by the southwestward migration of magmatism from the Paleogene to the Pliocene-Pleistocene in Macedonia and northern Greece.

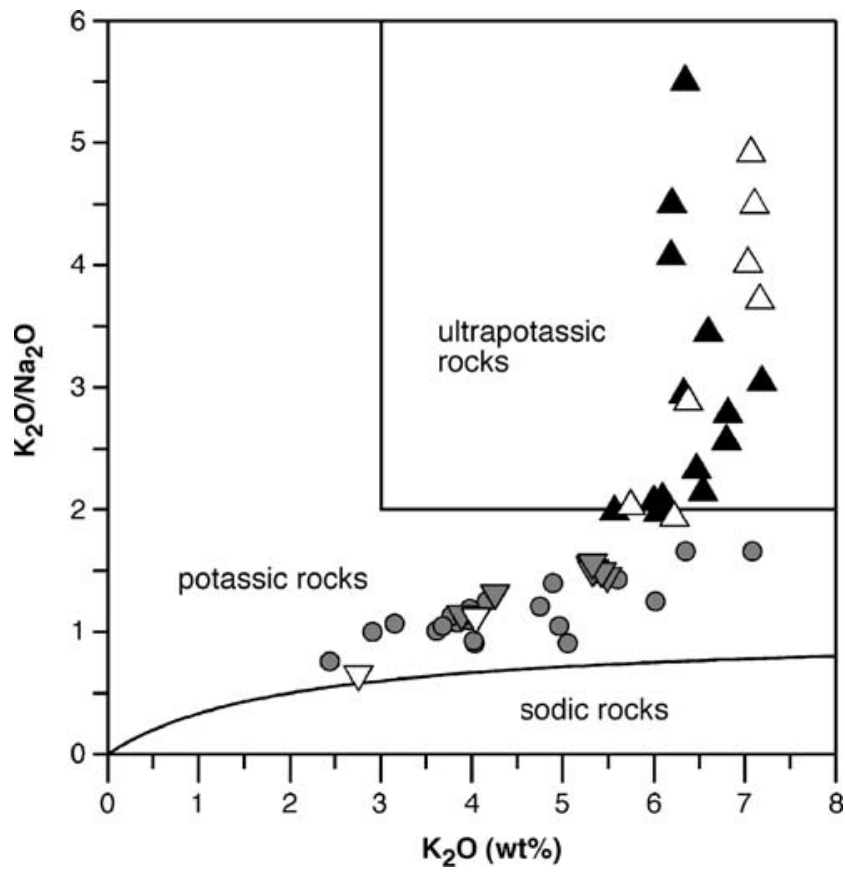

Fig. $4 \mathrm{~K}_{2} \mathrm{O} / \mathrm{Na}_{2} \mathrm{O}$ vs $\mathrm{K}_{2} \mathrm{O}$ (wt\%) diagram. Ultrapotassic rocks are defined following the chemical criteria of Foley et al. (1987). The line separating sodic and potassic rocks was drawn according to Le Maitre (1989). Symbols as in Fig. 3 
Table 1 Major and trace element concentrations and $\mathrm{Sr}-\mathrm{Nd}$ isotope ratios of selected samples

\begin{tabular}{lllllllllll}
\hline Sample & KZ 3 & KZ 5 & KZ 6 & KZ 7 & KZ 11 & KZ 12 & KZ 13 & KZ 15 & KZ 16 & KZ 17 \\
Locality & M. Chuka & Mt Porta & Mt Porta & Mt Porta & Sokol & Golubec & Golubec & Vasov Grad & Pulevatz & Pulevatz \\
rock type & Trachyte & Latite & Latite & Shoshonite & Trachyte & Shoshonite & Trachyte & Latite & Latite & Latite \\
group & LMg-K & LMg-K & LMg-K & LMg-K & LMg-K & LMg-K & LMg-K & LMg-K & LMg-K & LMg-K
\end{tabular}

\begin{tabular}{|c|c|c|c|c|c|c|c|c|c|c|}
\hline \multicolumn{11}{|c|}{ Major elements } \\
\hline $\mathrm{SiO}_{2}(\mathrm{wt} \%)$ & 64.43 & 58.54 & 61.66 & 51.88 & 61.58 & 52.54 & 62.67 & 61.36 & 56.87 & 57.19 \\
\hline $\mathrm{TiO}_{2}$ & 0.37 & 0.68 & 0.57 & 1.16 & 0.64 & 0.92 & 0.54 & 0.62 & 0.66 & 0.66 \\
\hline $\mathrm{Al}_{2} \mathrm{O}_{3}$ & 18.15 & 18.36 & 17.63 & 19.25 & 17.74 & 18.06 & 17.64 & 17.35 & 17.44 & 17.15 \\
\hline $\mathrm{Fe}_{2} \mathrm{O}_{3}(\mathrm{t})$ & 3.06 & 5.23 & 4.56 & 7.84 & 4.43 & 8.85 & 4.50 & 4.87 & 5.38 & 5.31 \\
\hline $\mathrm{FeO}$ & - & - & - & - & - & - & - & - & - & - \\
\hline $\mathrm{MnO}$ & 0.04 & 0.10 & 0.09 & 0.11 & 0.06 & 0.16 & 0.10 & 0.09 & 0.12 & 0.07 \\
\hline $\mathrm{MgO}$ & 1.43 & 2.85 & 2.40 & 4.69 & 2.38 & 3.85 & 1.90 & 2.87 & 3.17 & 3.04 \\
\hline $\mathrm{CaO}$ & 3.59 & 5.22 & 4.82 & 7.62 & 3.83 & 7.55 & 4.33 & 5.40 & 5.56 & 5.79 \\
\hline $\mathrm{Na}_{2} \mathrm{O}$ & 4.32 & 3.53 & 3.57 & 2.89 & 3.29 & 3.18 & 3.46 & 3.53 & 3.58 & 3.45 \\
\hline $\mathrm{K}_{2} \mathrm{O}$ & 3.99 & 3.54 & 3.81 & 2.86 & 3.68 & 2.38 & 3.86 & 3.67 & 5.28 & 4.78 \\
\hline $\mathrm{P}_{2} \mathrm{O}_{5}$ & 0.10 & 0.30 & 0.26 & 0.49 & 0.26 & 0.49 & 0.25 & 0.28 & 0.43 & 0.43 \\
\hline LOI & 0.79 & 1.30 & 1.23 & 1.33 & 1.94 & 1.99 & 1.33 & 0.57 & 1.13 & 2.71 \\
\hline Total & 100.27 & 99.65 & 100.60 & 100.12 & 99.83 & 99.97 & 100.58 & 100.61 & 99.62 & 100.58 \\
\hline $\mathrm{Mg} \#$ & 57.3 & 59.5 & 58.6 & 60.9 & 60.7 & 53.1 & 54.8 & 61.3 & 61.3 & 60.7 \\
\hline \multicolumn{11}{|c|}{ Trace elements } \\
\hline $\mathrm{Li}(\mathrm{ppm})$ & - & - & - & - & - & - & - & - & - & - \\
\hline $\mathrm{Be}$ & 3.8 & 4.3 & 4.3 & 3.5 & 3.5 & 6.4 & 4.1 & 4.3 & 7.5 & 6.1 \\
\hline $\mathrm{Sc}$ & 13 & 18 & 15 & 20 & 17 & 23 & 14 & 17 & 19 & 18 \\
\hline $\mathrm{V}$ & 46 & 102 & 86 & 179 & 97 & 162 & 81 & 97 & 141 & 127 \\
\hline $\mathrm{Cr}$ & 24 & 15 & 11 & 19 & 12 & 60 & 13 & 28 & 27 & 24 \\
\hline Co & 7 & 14 & 12 & 24 & 13 & 20 & 11 & 13 & 16 & 15 \\
\hline $\mathrm{Ni}$ & 17 & 12 & 12 & 19 & 13 & 26 & 10 & 16 & 16 & 18 \\
\hline $\mathrm{Cu}$ & 10 & 16 & 16 & 32 & 14 & 33 & 13 & 16 & 75 & 38 \\
\hline $\mathrm{Ga}$ & 18.4 & 19 & 18 & 18 & 17 & 20 & 17 & 17 & 19 & 18 \\
\hline $\mathrm{Rb}$ & 129 & 109 & 150 & 97 & 121 & 74 & 130 & 120 & 198 & 173 \\
\hline $\mathrm{Sr}$ & 1284 & 1156 & 1169 & 1359 & 1192 & 1342 & 1154 & 1270 & 1143 & 1376 \\
\hline $\mathrm{Y}$ & 11.5 & 21.1 & 18.3 & 22.6 & 17.5 & 30.4 & 15.9 & 18.5 & 28.1 & 22.7 \\
\hline $\mathrm{Zr}$ & 81 & 94 & 76 & 160 & 76 & 37 & 45 & 77 & 295 & 33 \\
\hline $\mathrm{Nb}$ & 9 & 12 & 11 & 13 & 11 & 14 & 11 & 11 & 20 & 18 \\
\hline $\mathrm{Cs}$ & 11 & 9.0 & 12.7 & 7.2 & 7.6 & 6.5 & 9.4 & 9.0 & 5.0 & 12.9 \\
\hline $\mathrm{Ba}$ & 2007 & 1533 & 1414 & 1530 & 1656 & 1099 & 1684 & 1591 & 1743 & 1735 \\
\hline $\mathrm{La}$ & 58 & 73 & 71 & 60 & 63 & 49 & 57 & 69 & 85 & 79 \\
\hline $\mathrm{Ce}$ & 102 & 130 & 132 & 118 & 119 & 109 & 112 & 131 & 159 & 156 \\
\hline $\operatorname{Pr}$ & 10.6 & 15.3 & 14.3 & 14.4 & 13.6 & 16.0 & 12.3 & 14.5 & 18.1 & 17.8 \\
\hline $\mathrm{Nd}$ & 35 & 53 & 49 & 54 & 49 & 67 & 44 & 52 & 65 & 64 \\
\hline $\mathrm{Sm}$ & 4.7 & 7.8 & 6.8 & 8.5 & 6.8 & 12.0 & 6.4 & 7.6 & 10.5 & 10.3 \\
\hline $\mathrm{Eu}$ & 0.26 & 1.51 & 1.13 & 1.57 & 0.98 & 2.32 & 1.09 & 0.96 & 1.69 & 1.56 \\
\hline $\mathrm{Gd}$ & 3.6 & 5.6 & 4.7 & 6.2 & 5.1 & 8.0 & 4.7 & 5.6 & 8.0 & 7.1 \\
\hline $\mathrm{Tb}$ & 0.39 & 0.69 & 0.61 & 0.79 & 0.63 & 1.07 & 0.56 & 0.69 & 1.04 & 0.87 \\
\hline Dy & 1.91 & 3.6 & 3.10 & 4.1 & 3.2 & 5.6 & 2.84 & 3.3 & 5.2 & 4.4 \\
\hline Ho & 0.37 & 0.72 & 0.57 & 0.78 & 0.60 & 1.02 & 0.53 & 0.63 & 0.97 & 0.78 \\
\hline $\mathrm{Er}$ & 1.02 & 1.93 & 1.66 & 2.12 & 1.56 & 2.71 & 1.47 & 1.61 & 2.49 & 1.98 \\
\hline $\mathrm{Tm}$ & 0.15 & 0.30 & 0.25 & 0.30 & 0.21 & 0.39 & 0.22 & 0.25 & 0.35 & 0.26 \\
\hline $\mathrm{Yb}$ & 0.95 & 1.82 & 1.65 & 1.93 & 1.49 & 2.51 & 1.30 & 1.59 & 2.30 & 1.63 \\
\hline $\mathrm{Lu}$ & 0.15 & 0.27 & 0.25 & 0.28 & 0.22 & 0.34 & 0.19 & 0.22 & 0.32 & 0.21 \\
\hline Hf & 2.50 & 2.90 & 2.40 & 4.4 & 2.60 & 1.80 & 1.70 & 2.30 & 8.2 & 1.32 \\
\hline $\mathrm{Ta}$ & 0.63 & 0.89 & 0.87 & 0.75 & 0.80 & 0.67 & 0.85 & 0.84 & 1.33 & 1.21 \\
\hline $\mathrm{Tl}$ & 0.90 & 1.10 & 1.0 & 0.70 & 0.80 & 0.40 & 0.70 & 0.90 & 1.20 & 2.0 \\
\hline $\mathrm{Pb}$ & 85 & 60 & 62 & 38 & 55 & 43 & 59 & 71 & 79 & 96 \\
\hline Th & 24.9 & 28.8 & 31.0 & 17.4 & 25.7 & 8.9 & 25.5 & 30.0 & 54 & 41.0 \\
\hline $\mathrm{U}$ & 7.8 & 8.0 & 8.0 & 3.7 & 7.5 & 3.3 & 7.4 & 8.6 & 16.0 & 8.7 \\
\hline${ }^{87} \mathrm{Sr} /{ }^{86} \mathrm{Sr}$ & 0.709162 & & 0.708868 & 0.708706 & & & & 0.709280 & 0.709318 & \\
\hline${ }^{143} \mathrm{Nd} /{ }^{144} \mathrm{Nd}$ & 0.512298 & & 0.512320 & 0.512334 & & & & 0.512304 & 0.512300 & \\
\hline
\end{tabular}

- not determined 


\begin{tabular}{|c|c|c|c|c|c|c|c|c|c|c|}
\hline KZ 18 & KZ 22 & GU 5 & MN 11 & CER1 & SLAV & EB 2 & GR 3 & K 01 & MN 13 & MN 9 \\
\hline Staravina & Gradesnica & Djurishte & Djurishte & Cer & Slavujevci & Jezevo Brdo & Gradishte & K. Krasta & M. Negor. & Kishino \\
\hline Trachyte & Trachyte & Latite & Latite & Shoshonite & Shoshonite & Ph-tephrite & Latite & Shoshonite & Ph-tephrite & Ph-tephrite \\
\hline LMg-K & $\mathrm{HMg}-\mathrm{K}$ & HMg-K & HMg-K & $\mathrm{HMg}-\mathrm{K}$ & HMg-K & $\mathrm{HMg}-\mathrm{K}$ & UK & UK & UK & UK \\
\hline
\end{tabular}

\begin{tabular}{|c|c|c|c|c|c|c|c|c|c|c|}
\hline \multicolumn{11}{|c|}{ Major elements } \\
\hline 64.01 & 60.01 & 55.27 & 55.83 & 52.73 & 50.58 & 46.36 & 53.79 & 50.87 & 49.62 & 46.69 \\
\hline 0.29 & 0.54 & 0.94 & 0.92 & 1.23 & 0.99 & 2.19 & 1.15 & 1.47 & 1.16 & 1.23 \\
\hline 17.72 & 16.99 & 14.70 & 15.19 & 14.59 & 14.86 & 14.14 & 12.81 & 11.39 & 12.25 & 13.05 \\
\hline 2.31 & 4.72 & 2.49 & 5.72 & 4.46 & 4.41 & 4.40 & 2.25 & 2.58 & 7.24 & 8.71 \\
\hline- & - & 2.87 & - & 2.47 & 2.42 & 2.90 & 3.70 & 4.13 & - & - \\
\hline 0.09 & 0.09 & 0.11 & 0.11 & 0.13 & 0.13 & 0.12 & 0.12 & 0.11 & 0.12 & 0.15 \\
\hline 0.43 & 2.17 & 6.40 & 5.51 & 7.05 & 7.66 & 7.92 & 8.22 & 9.71 & 9.95 & 9.04 \\
\hline 1.63 & 4.89 & 6.18 & 6.08 & 7.38 & 9.90 & 8.82 & 6.26 & 8.91 & 7.80 & 10.0 \\
\hline 4.17 & 5.61 & 3.57 & 3.71 & 3.30 & 3.49 & 2.08 & 2.86 & 1.49 & 2.35 & 2.78 \\
\hline 6.90 & 5.06 & 5.29 & 5.41 & 4.21 & 3.86 & 6.11 & 5.98 & 6.07 & 7.14 & 5.50 \\
\hline 0.0 & 0.32 & 0.99 & 1.09 & 1.20 & 0.95 & 1.50 & 0.97 & 1.33 & 1.65 & 1.62 \\
\hline 3.39 & 0.99 & 0.57 & 0.68 & 1.71 & 1.69 & 2.37 & 0.83 & 2.88 & 0.55 & 1.03 \\
\hline 100.94 & 101.39 & 99.38 & 100.25 & 100.46 & 100.94 & 98.91 & 98.94 & 100.94 & 99.83 & 99.80 \\
\hline 34.8 & 56.9 & 75.2 & 72.2 & 71.8 & 73.8 & 73.0 & 77.7 & 77.9 & 78.2 & 73.0 \\
\hline \multicolumn{11}{|c|}{ Trace elements } \\
\hline- & - & 12.86 & - & 13.93 & 12.42 & 9.03 & 10.03 & 12.58 & - & - \\
\hline 24.0 & 7.9 & 8.1 & 9.19 & 8.42 & 6.7 & 4.45 & 9.57 & 8.65 & 10.59 & 7.91 \\
\hline 10 & 16 & 18 & 18 & 19 & 20 & 23 & 19 & 25 & 24 & 28 \\
\hline 34 & 100 & 125 & 111 & 159 & 144 & 184 & 131 & 182 & 168 & 195 \\
\hline 3 & 23 & 227 & 231 & 314 & 184 & 173 & 383 & 420 & 407 & 263 \\
\hline 3 & 12 & 23 & 24 & 31 & 29 & 32 & 29 & 34 & 36 & 34 \\
\hline 4 & 12 & 132 & 134 & 194 & 159 & 146 & 243 & 131 & 235 & 98 \\
\hline 6 & 22 & - & - & 44 & 28 & - & - & - & - & - \\
\hline 22 & 19 & 16 & 16 & 16.0 & 16 & 17 & 17 & 15 & 15 & 15 \\
\hline 425 & 194 & 229 & 233 & 96 & 369 & 388 & 284 & 252 & 332 & 228 \\
\hline 268 & 1209 & 1341 & 1340 & 1069 & 1281 & 2104 & 1596 & 1041 & 1115 & 1311 \\
\hline 23.4 & 24.0 & 24.56 & 24.52 & 27.97 & 28.2 & 26.12 & 28.17 & 22.32 & 25.36 & 29.79 \\
\hline 465 & 188 & 321 & 312 & 330 & 291 & 415 & 497 & 458 & 319 & 342 \\
\hline 44 & 20 & 24.0 & 25 & 26 & 22 & 30.0 & 22 & 25 & 20 & 25 \\
\hline 84.1 & 19.7 & 9.9 & 9.3 & 15.5 & 12.9 & 10.1 & 6.3 & 14.7 & 24.9 & 14.9 \\
\hline 316 & 1562 & 2500 & 2409 & 2312 & 1771 & 4163 & 2668 & 2268 & 2545 & 2263 \\
\hline 149 & 84 & 67 & 68 & 48 & 59 & 116 & 99 & 54 & 37 & 56 \\
\hline 233 & 160 & 130 & 130 & 96 & 119 & 243 & 223 & 126 & 81 & 120 \\
\hline 20.8 & 17.3 & 14.9 & 15.0 & 11.8 & 14.5 & 28.9 & 29.4 & 17.1 & 10.7 & 15.4 \\
\hline 60 & 60 & 54.6 & 55.4 & 45.6 & 54.5 & 109.3 & 119.1 & 70.2 & 43.8 & 62.6 \\
\hline 7.7 & 9.3 & 8.8 & 8.7 & 8.0 & 9.0 & 15.7 & 16.5 & 10.6 & 8.5 & 11.3 \\
\hline 1.21 & 1.47 & 1.54 & 1.50 & 1.95 & 2.18 & 2.32 & 2.93 & 1.63 & 1.37 & 2.28 \\
\hline 5.5 & 6.7 & 6.7 & 6.5 & 6.1 & 6.6 & 10.5 & 9.6 & 7.0 & 6.6 & 8.5 \\
\hline 0.68 & 0.81 & 0.84 & 0.83 & 0.85 & 0.87 & 1.09 & 1.10 & 0.82 & 0.89 & 1.09 \\
\hline 3.5 & 4.4 & 4.3 & 4.3 & 4.6 & 4.8 & 5.2 & 5.3 & 4.3 & 4.7 & 5.7 \\
\hline 0.69 & 0.80 & 0.86 & 0.81 & 0.95 & 0.96 & 0.92 & 0.99 & 0.75 & 0.86 & 1.03 \\
\hline 2.07 & 2.14 & 2.20 & 2.17 & 2.50 & 2.57 & 2.21 & 2.46 & 1.86 & 2.15 & 2.50 \\
\hline 0.35 & 0.33 & 0.34 & 0.34 & 0.38 & 0.39 & 0.31 & 0.33 & 0.28 & 0.33 & 0.38 \\
\hline 2.41 & 2.09 & 2.08 & 2.04 & 2.29 & 2.34 & 1.92 & 2.26 & 1.69 & 1.94 & 2.22 \\
\hline 0.36 & 0.30 & 0.30 & 0.32 & 0.33 & 0.36 & 0.27 & 0.32 & 0.23 & 0.29 & 0.33 \\
\hline 13.2 & 5.5 & 8.0 & 8.0 & 8.4 & 7.1 & 10.6 & 12.8 & 11.8 & 8.3 & 8.7 \\
\hline 1.95 & 1.42 & 1.35 & 1.39 & 1.45 & 1.40 & 1.39 & 1.10 & 1.23 & 1.04 & 1.47 \\
\hline 3.90 & 2.10 & 0.59 & 0.27 & 1.31 & 0.59 & 1.46 & 1.82 & 2.31 & 2.07 & 1.86 \\
\hline 128 & 81 & 46 & 35 & 30 & 31 & 26 & 34 & 19 & 40 & 36 \\
\hline 165.0 & 56 & 31.2 & 31.9 & 23.7 & 26.1 & 25.5 & 68.2 & 43.1 & 23.8 & 26.3 \\
\hline \multirow[t]{3}{*}{47.0} & 15.3 & 8.4 & 8.13 & 7.48 & 8.23 & 4.73 & 7.83 & 7.5 & 8.58 & 7.47 \\
\hline & 0.708938 & 0.71 & 0.708150 & 0.71 & 0.71 & 0.708693 & 0.710404 & 0.710090 & 0.71 & \\
\hline & 0.512317 & 0.51 & 0.51 & 0.51 & 0.51 & 0.512359 & 0.512149 & 0.512224 & 0.51 & \\
\hline
\end{tabular}




\section{Analytical methods}

$\mathrm{K}$-Ar ages were determined on whole rock samples at ATOMKI, in Debrecen (Hungary). The groundmass was separated using standard techniques and purified by handpicking under a stereomicroscope. About $500 \mathrm{mg}$ of sample were spiked with ${ }^{38} \mathrm{Ar}$ for the determination of ${ }^{40} \mathrm{Ar}$. The mass spectrometer, operating in static mode, was cleaned with conventional getter material before introducing the gas sample. Interlaboratory standards HD-B1, GLO, LP-6 and Asia 1/65 were used for calibration. Ages were calculated according to the decay constants of Steiger and Jäger (1977). All analytical uncertainties are reported as single standard deviations. Potassium concentrations were determined by flame photometry, adding $100 \mathrm{mg} / \mathrm{l}$ of $\mathrm{Na}$ and $\mathrm{Li}$ to $\sim 100 \mathrm{mg}$ dissolved sample. Major and trace element analyses were performed at the Pisa University's Dipartimento di Scienze della Terra. Major elements were determined by X-ray fluorescence on an ARL $9400 \mathrm{XP}+$ spectrometer using $\mathrm{Li}_{2} \mathrm{~B}_{4} \mathrm{O}_{7}$ glass disks. Estimated precision (relative standard deviation, RSD) is about $1 \%$ for $\mathrm{SiO}_{2}$ and about $2 \%$ for the other major elements except those with low concentrations (approximately $<0.50 \mathrm{wt} \%$ ), for which the absolute standard deviation is about $\pm 0.01 \%$. Loss on ignition (LOI) was determined by gravimetry at $1,000^{\circ} \mathrm{C}$ after preheating at $110^{\circ} \mathrm{C}$. The concentrations of a set of 35 trace elements were determined by inductively coupled plasma-mass spectrometry (VG PQII Plus). Sample powders were dissolved in PFA vessels on a hot plate at about $120^{\circ} \mathrm{C}$ using $\mathrm{HF}+\mathrm{HNO}_{3}$. The sample solutions, spiked with $\mathrm{Rh}, \mathrm{Re}$ and $\mathrm{Bi}$ as internal standards, were measured by external calibration using international reference materials of basaltic composition. Analytical precision (assessed through replicate analyses) is between 2 and 5\% $\mathrm{RSD}$, except for $\mathrm{Gd}, \mathrm{Tm}, \mathrm{Be}, \mathrm{Sc}, \mathrm{Pb}$ (6-8\% RSD).

$\mathrm{Sr}$ and $\mathrm{Nd}$ isotope compositions were measured with a Finnigan MAT 262 multicollector mass spectrometer at the Istituto di geoscienze e Georisorse, CNR, Pisa. Conventional ion exchange methods were used for $\mathrm{Sr}$ and $\mathrm{Nd}$ separations. Measured ${ }^{87} \mathrm{Sr} /{ }^{86} \mathrm{Sr}$ ratios were normalized to ${ }^{86} \mathrm{Sr} /{ }^{88} \mathrm{Sr}=0.1194,{ }^{143} \mathrm{Nd} /{ }^{144} \mathrm{Nd}$ ratios to ${ }^{146} \mathrm{Nd} /{ }^{144} \mathrm{Nd}=0.7219$. During the collection of isotopic data for this study, replicate measurements of NIST SRM 987 $\left(\mathrm{SrCO}_{3}\right)$ and La Jolla standards gave values of $0.710243 \pm$ 13 (2SD, $N=20$ ) for ${ }^{87} \mathrm{Sr} /{ }^{86} \mathrm{Sr}$ and $0.511848 \pm 7$ (2SD, $N=$ 30) for ${ }^{143} \mathrm{Nd} /{ }^{144} \mathrm{Nd}$.

\section{Sample location}

The studied volcanic rocks crop out in the Vardar Zone, south of the Scutari-Peć transverse fault zone considered to be the northern limit of Aegean extension (Kissel et al. 1995). Figure 2 reports the locations of the studied volcanic centres. The volume of emitted products is generally limited; they form small, thin, lava flows, which are in some cases connected with the feeder dykes, as in the Kureshnichka Krasta and Jezevo Brdo areas, where eroded remnants of vents (necks) are also present. The volcanic cover at Mlado Nagorichane is 10 to $30 \mathrm{~m}$ thick and has the greatest extension, covering an area of about $15 \mathrm{~km}^{2}$. It consists of several superimposed lava flows separated by thin scoria levels. In addition, volcanics from Cer and Slavujevci in southern Serbia were sampled and analyzed. Noteworthy, the lavas of Jezevo Brdo and Kureshnichka Krasta crop out in the area of the NW-trending active faults of Skopje and Lakavica (Dumurdzanov et al. 2005), from which they were erupted.

The large Kozuf Massif (named Voras Massif in Greece) is the southernmost volcanic area sampled in this study. It comprises a cluster of domes, pyroclastics and subordinate lava flows; 22 samples from the Macedonian part of this massif were analyzed.
Fig. $5 \mathrm{CaO}$ vs $\mathrm{SiO}_{2}$ (a), and $\mathrm{CaO}$ vs $\mathrm{Al}_{2} \mathrm{O}_{3}$ (b) (wt\%) diagrams. Boundary lines between Group I and Group III ultrapotassic rocks are slightly modified from Foley et al. (1987). Symbols as in Fig. 3
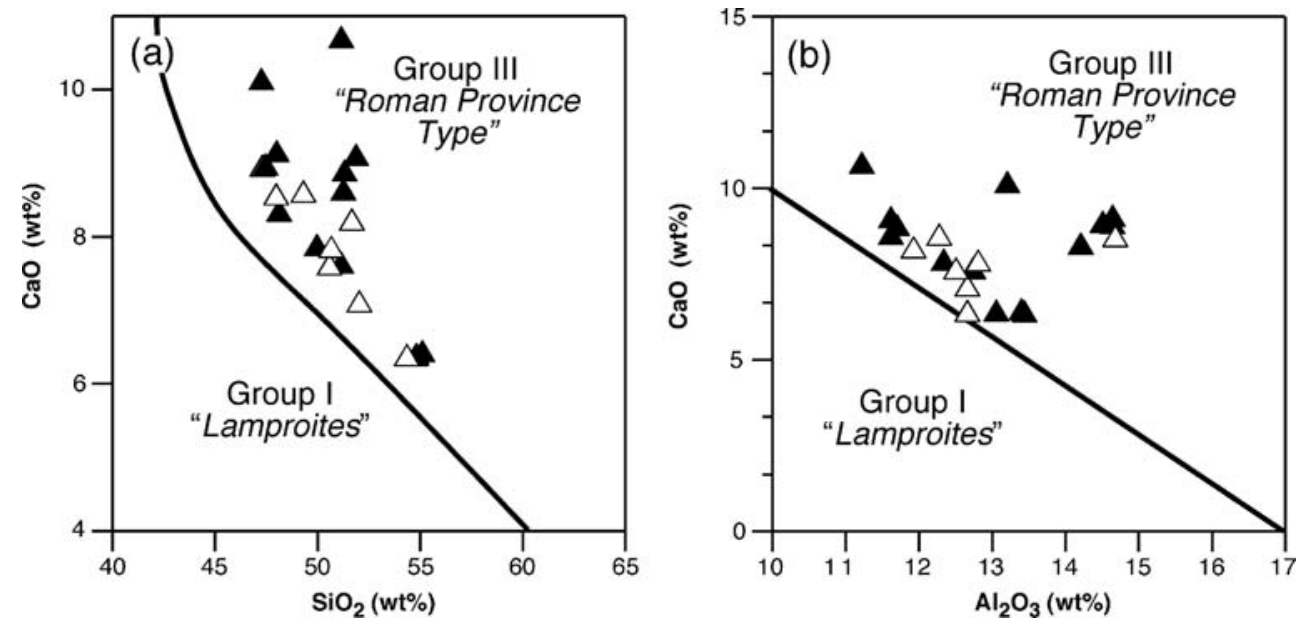


\section{Results}

Petrography and mineral chemistry

The Neogene volcanic rocks from the Vardar Zone constitute a complex association with a potassic $(\mathrm{K})$ to ultrapotassic (UK, sensu Foley et al. 1987) alkaline and transitional signature (Figs. 3 and 4). For their classification we mainly followed the IUGS criteria, as reported in Le Maitre (2002).

The rocks of this study were divided into three groups: (1) ultrapotassic rocks (shoshonite, phonotephrite, latite); 2) high-Mg potassic rocks (HMg-K; shoshonite, phonoteph- rite, latite with $\mathrm{MgO}>5 \mathrm{wt} \%)$; 3) low-Mg potassic rocks from Kozuf-Voras Massif (LMg-K; shoshonite, latite, trachyte, rhyolite with $\mathrm{MgO}<5 \mathrm{wt} \%$ ).

A synopsis of petrographical and mineralogical features of the studied rocks are reported in the following paragraphs.

$L M g-K$ Group These rocks are exposed only in the southern part of the Vardar Zone, in the Kozuf-Voras Massif. They are mildly alkaline to transitional (Fig. 3), with potassic affinity and a $\mathrm{K}_{2} \mathrm{O} / \mathrm{Na}_{2} \mathrm{O}$ ratio generally less than 1.8 (Fig. 4, Table 1). These rocks are considered to form a shoshonitic association; they are silica-oversaturated, except samples KZ7 and KZ14, which are olivine- and hypersthene-

Table 2 Summary of petrological and chemical characteristics of the studied rocks

\begin{tabular}{|c|c|c|c|c|c|}
\hline Locality & Rock type & Group & Texture & $\begin{array}{l}\text { Phenocrysts/ } \\
\text { microphenocryst }\end{array}$ & Groundmass \\
\hline Cer & $\begin{array}{l}\text { Shoshonite } \\
\mathrm{K}_{2} \mathrm{O} / \mathrm{Na}_{2} \mathrm{O}=1.8\end{array}$ & $\mathrm{HMg}-\mathrm{K}$ & $\begin{array}{l}\text { Porphyritic } \\
\text { Gm-poikilitic }\end{array}$ & Ol, Cpx, Phl & Na-San, Pl, Ti-Mg, Ilm, Ap \\
\hline Slavujevci & $\begin{array}{l}\text { shoshonite } \\
\mathrm{K}_{2} \mathrm{O} / \mathrm{Na}_{2} \mathrm{O}=1.1 \\
\mathrm{Ne} \text { (norm) } 8.3\end{array}$ & $\mathrm{HMg}-\mathrm{K}$ & $\begin{array}{l}\text { Porphyritic } \\
\text { Gm-poikilitic }\end{array}$ & Ol, Cpx, Phl, Pl & $\mathrm{Pl}, \mathrm{Mg}, \mathrm{Ap}$, analcime \\
\hline \multirow[t]{2}{*}{ M. Nagorichane } & phonotephrite & UK & Porphyritic & $\mathrm{Ol}, \mathrm{Cpx}, \mathrm{Lc}$ & $\begin{array}{l}\text { Na-San, Ba-Ti Phl, Cpx, Ti-Mg, } \\
\text { Ap, Lc altered into zeolite }\end{array}$ \\
\hline & $\begin{array}{l}\mathrm{K}_{2} \mathrm{O} / \mathrm{Na}_{2} \mathrm{O}=2.8-4.5 \\
\mathrm{Ne} \text { (norm) } 8-11+\mathrm{Lc} \\
\text { (norm) } 1.0\end{array}$ & & Gm-poikilitic & & \\
\hline Gradishte & $\begin{array}{l}\text { Latite to UK-latite } \\
\mathrm{K}_{2} \mathrm{O} / \mathrm{Na}_{2} \mathrm{O}=2.0-2.1 ; \\
\mathrm{Ne} \text { (norm) } 0.6-1.7\end{array}$ & UK & $\begin{array}{l}\text { Porphyritic } \\
\text { Gm-trachytic }\end{array}$ & $\mathrm{Ol}, \mathrm{Cpx}, \mathrm{Phl}$ & Cpx, Na-San, Phl, Ti-Mg, Ap \\
\hline Djurishte & $\begin{array}{l}\text { Latite to shoshonite } \\
\mathrm{K}_{2} \mathrm{O} / \mathrm{Na}_{2} \mathrm{O}=1.4-1.5 \\
\mathrm{Ne} \text { (norm) } 0.3-1.8 \\
\text { or hy } 0.8\end{array}$ & $\mathrm{HMg}-\mathrm{K}$ & $\begin{array}{l}\text { Porphyritic } \\
\text { Gm-poikilitic }\end{array}$ & Ol, Cpx, Phl & Cpx, Phl, Na-San, Ti-Mg, Ilm, Ap \\
\hline \multirow[t]{2}{*}{ Jezevo Brdo } & Phonotephrite & UK & Microporphyritic & Ol, Cpx, Ti-Phl & $\begin{array}{l}\text { Anorth, } \mathrm{Pl}, \mathrm{Phl}, \mathrm{Na}-\mathrm{San}, \mathrm{Mg}- \\
\text { bearing carbonate, } \mathrm{Cpx}, \mathrm{Lc} \\
\text { (with } \mathrm{Cpx} \text { inclusion) }\end{array}$ \\
\hline & $\mathrm{K}_{2} \mathrm{O} / \mathrm{Na}_{2} \mathrm{O}=1.9-2.9$ & & Gm-poikilitic & & \\
\hline \multirow[t]{3}{*}{ Kishino } & $\begin{array}{l}\text { Lc (norm) } 0.9-6.6 \\
\text { phonotephrite }\end{array}$ & UK & Porphyritic & Ol, Analcime & $\begin{array}{l}\text { Cpx, Ol, Na-San, Anorth, Ti-Phl, } \\
\text { Ti-Mg, Ap, Carbonate, zeolite }\end{array}$ \\
\hline & $\mathrm{K}_{2} \mathrm{O} / \mathrm{Na}_{2} \mathrm{O}=2.0$ & & Gm-microlitic & & \\
\hline & Lc (norm) 5.7 & & & & \\
\hline \multirow[t]{2}{*}{ K. Krasta } & $\begin{array}{l}\text { Phonotephrite to } \\
\text { UK-shoshonite }\end{array}$ & UK & Porphyritic & Ol, Cpx, Phl & $\begin{array}{l}\text { Na-San, Phl, Cpx, Ol, Lc (altered } \\
\text { into zeolites+clays), Ti-Mg, Ap }\end{array}$ \\
\hline & $\begin{array}{l}\mathrm{K}_{2} \mathrm{O} / \mathrm{Na}_{2} \mathrm{O}=3.5-5.5 \\
\mathrm{Ne} \text { (norm) } 1.5-5.5\end{array}$ & & Gm-poikilitic & & \\
\hline \multirow[t]{2}{*}{ Kozuf } & $\begin{array}{l}\text { Shoshonites to } \\
\text { rhyolites }\end{array}$ & $\mathrm{LMg}-\mathrm{K}$ & Porphyritic & $\begin{array}{l}\mathrm{Pl} \text {, San, Amph, } \\
\mathrm{Bt}\end{array}$ & $\mathrm{Pl}$, San, Bt, Mg \\
\hline & $\mathrm{K}_{2} \mathrm{O} / \mathrm{Na}_{2} \mathrm{O}=0.8-1.6$ & & $\begin{array}{l}\text { Gm-holohyaline to } \\
\text { holocrystalline } \\
\text { ipidiomorphic }\end{array}$ & & \\
\hline
\end{tabular}

Ol olivine, $C p x$ clinopyroxene, $P h l$ phlogopite, Amph amphibole, San sanidine, Anorth anorthoclase, Gm groundmass, $L c$ leucite, Ne nepheline, $\mathrm{Mg}$ magnetite, $\mathrm{Ilm}$ ilmenite, $\mathrm{Ap}$ apatite, $\mathrm{Pl}$ plagioclase, Bt biotite 
normative, and samples KZ21 and KZ22, which are nepheline-normative. All rocks are porphyritic, with variable amounts of glass in the groundmass; in some cases a porphyritic holohyaline texture is observed. The groundmass is about $50-70$ vol.\% of the total rock volume and generally contains the same minerals present as phenocrysts. The phenocryst assemblage consists of zoned plagioclase (from labradorite to oligoclase), hornblende and biotite; biotite becomes more abundant in the more evolved rocks. Sanidine occurs sporadically in latites and becomes significantly more abundant in trachytes, where it can locally reach centimeter size. Scattered clinopyroxene is mainly observed in shoshonites and latites. Opaque minerals are represented by Ti-magnetite and rare ilmenite.

$H M g-K$ Group This group shows a shoshonitic affinity, like the Kozuf samples, but with higher alkalinity $\left(\mathrm{Na}_{2} \mathrm{O}+\mathrm{K}_{2} \mathrm{O}>\right.$ $7 \mathrm{wt} \%$ ), a $\mathrm{K}_{2} \mathrm{O}$ content generally $>4 \mathrm{wt} \%$, and a $\mathrm{K}_{2} \mathrm{O} / \mathrm{Na}_{2} \mathrm{O}$ ratio of 1.0 to 1.8 (Figs. 3 and 4). The rocks are generally saturated or slightly undersaturated in $\mathrm{SiO}_{2}$ (highest normative Ne content $=8.3 \%$, Slavujevci). In addition, they exhibit relatively high $\mathrm{MgO}$ contents with $\mathrm{Mg} \#[100 \mathrm{Mg} /(\mathrm{Mg}+$ $\left.\left.\mathrm{Fe}^{2+}\right)\right]>70$, in contrast to $\mathrm{Mg} \#<61$ of the Kozuf rocks.

These rocks show a porphyritic texture; in shoshonites and latites, the phenocrysts are represented by the associ-

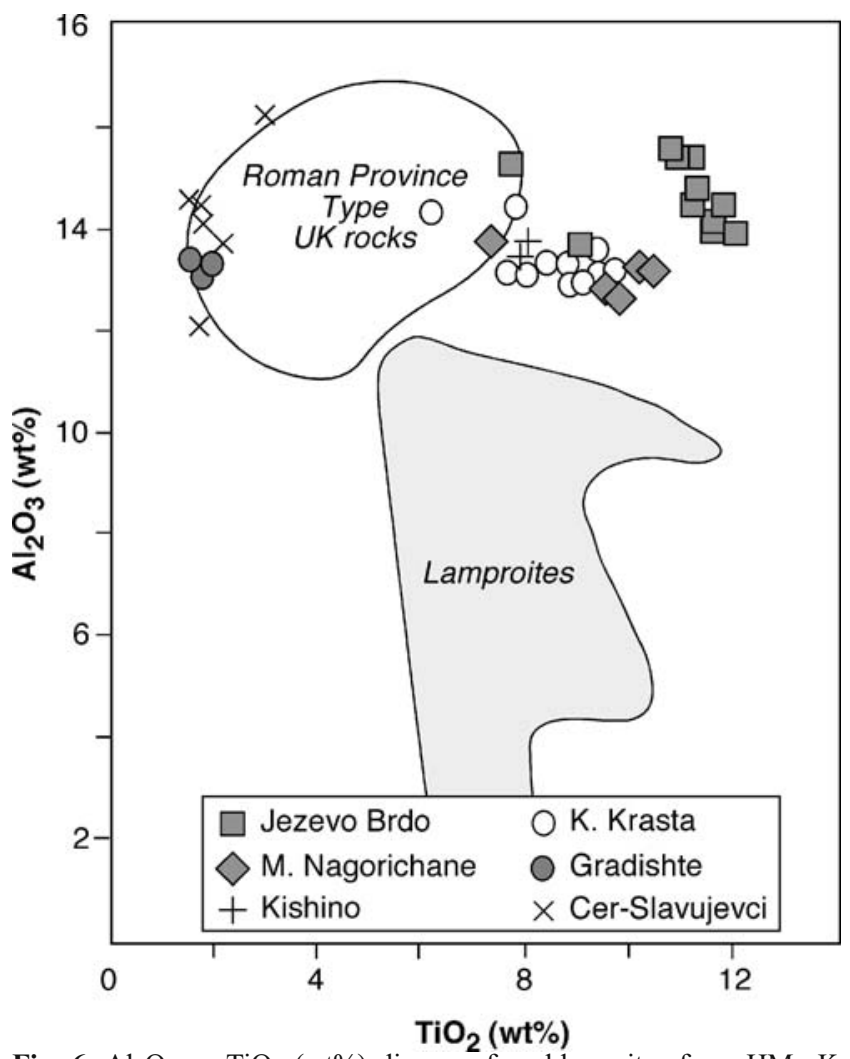

Fig. $6 \mathrm{Al}_{2} \mathrm{O}_{3}$ vs $\mathrm{TiO}_{2}(\mathrm{wt} \%$ ) diagram for phlogopites from $\mathrm{HMg}-\mathrm{K}$ and UK rocks from southern Serbia and Macedonia. Group III (Roman Province-type) and Group I (Lamproites) fields redrawn after Prelević et al. (2005)
Table $3 \mathrm{~T}$ and $\mathrm{P}$ estimates

\begin{tabular}{lllc}
\hline Locality & Rock type & $T\left({ }^{\circ} \mathrm{C}\right)$ & $\mathrm{P}(\mathrm{GPa})$ \\
\hline M. Nagorichane & Phonotephrite & $1,298(1)$ & \\
& & $1,312(2)$ & \\
Kishino & Phonotephrite & $1,259(1)$ & \\
& & $1,284(2)$ & \\
Jezevo Brdo & Phonotephrite & $1,287(1)$ & \\
& & $1,262(2)$ & \\
& & $1,144(3)$ & 0.7 \\
Gradishte & $1,259(1)$ & \\
& UK-Latite & $1,267(2)$ & \\
& & $1,298(3)$ & 1.7 \\
Djurishte & K-Latite & $1,189(1)$ & \\
& & $1,210(2)$ & \\
& & $1,198(3)$ & 0.8 \\
K.Krasta & UK-Sho & $1,310(1)$ & \\
& & $1,290(2)$ & \\
& & $1,278(3)$ & 1.2 \\
& &
\end{tabular}

(1) Putirka et al. (2007); (2) Beattie (1993); (3) Putirka et al. (2003)

ation of Mg-rich olivine ( $\mathrm{Fo}_{80-88}$ ), phlogopite, clinopyroxene and rare andesine plagioclase. The groundmass includes small amounts of recrystallized glass, sanidine, pyroxene, phlogopite, Ti-magnetite and apatite; Djurishte lavas also contain ilmenite. In the literature these rocks have been classified as UK rocks with lamproitic affinity (e.g. Prelević et al. 2005; 2007; Cvetković et al. 2004; Altherr et al. 2004).

UK Group These rocks are highly primitive, with $\mathrm{MgO}$ generally $>7 \mathrm{wt} \%$ and $\mathrm{Mg} \#$ ranging between 71 and 79 . Although the rocks of this group have been considered lamproites, mainly on a mineralogical basis, i.e. the absence of plagioclase (Altherr et al. 2004), or on a chemical basis, i.e. $\mathrm{CaO}$ vs $\mathrm{MgO}$ diagram (Prelević et al. 2007), we consider them to have a Roman Type (Group III of Foley et al. 1987)-affinity because of their $\mathrm{CaO} / \mathrm{SiO}_{2}$ and $\mathrm{CaO} /$ $\mathrm{Al}_{2} \mathrm{O}_{3}$ ratios (Fig. 5; see following section) and the occurrence of groundmass feldspar in some lavas (i.e. Jezevo Brdo). The majority of studied samples show a porphyritic texture; phenocrysts are characterized by the presence of olivine, clinopyroxene (except Kishino lavas) and phlogopite. Leucite has been found in UK phonotephrites from Mlado Nagorichane. In some samples phenocrysts form glomeroporphyritic aggregates. Olivine, up to 1$2 \mathrm{~mm}$ in size, is generally slightly rounded and zoned (e.g. in Kureshnichka Krasta: cores $\mathrm{Fo}_{81-93}$, rims $\mathrm{Fo}_{74-83}$ ). Olivine rims and cracks are locally altered to serpentine minerals. Clinopyroxene has an average grain size of $1 \mathrm{~mm}$ and is slightly zoned (e.g. in Gradishte and Kureshnichka Krasta); it has a diopside-augite composition, with $\mathrm{Al}$ contents ranging from 0.43 to $4.95 \mathrm{wt} \%$ (Jezevo Brdo and Djurishte). Phlogopite, zoned and with Ba-rich cores, is 
Table $4 \mathrm{~K}-\mathrm{Ar}$ data

\begin{tabular}{llcccc}
\hline Locality & Material & $\mathrm{K}(\mathrm{wt} \%)$ & ${ }^{40} \mathrm{Ar}_{\text {rad }}(\mathrm{ccSTP} / \mathrm{g})$ & ${ }^{40} \mathrm{Ar}_{\text {rad }} \%$ & $\mathrm{~K}-\mathrm{Ar}$ age $(\mathrm{Ma}) \pm 1 \sigma$ \\
\hline M. Nagorichane & WR & 5.46 & $3.856 \times 10^{-7}$ & 40.4 & $1.81 \pm 0.07$ \\
Kishino & WR & 3.87 & $2.221 \times 10^{-7}$ & 24.3 & $1.47 \pm 0.09$ \\
Jezevo Brdo & WR & 5.05 & $6.369 \times 10^{-7}$ & 56.2 & $3.24 \pm 0.11$ \\
Gradishte & WR & 4.78 & $3.161 \times 10^{-7}$ & 32.8 & $1.70 \pm 0.08$ \\
Djurishte & WR & 4.24 & $5.259 \times 10^{-7}$ & 42.8 & $3.19 \pm 0.12$ \\
K. Krasta & WR & 4.85 & $3.848 \times 10^{-7}$ & 27.0 & $2.04 \pm 0.10$ \\
\hline
\end{tabular}

$W R$ whole rock

often extensively replaced by a magnetite and clinopyroxene assemblage. It has an $\mathrm{Mg \#}$ of 67 (rim) to 92 (core); the $\mathrm{Al}_{2} \mathrm{O}_{3}$ content is relatively high (12.6-15.5 wt $\left.\%\right)$. The latite and shoshonite from Gradishte and Kishino, contain phlogopite crystals with low $\mathrm{Ba}$ and $\mathrm{Ti} \quad(\approx 0.3 \mathrm{wt} \%$ and $\approx 1.7 \mathrm{wt} \%$, respectively) and relatively high $\mathrm{Cr}$ (up to $1 \mathrm{wt} \%$ for Gradishte rocks) contents; in contrast, the $\mathrm{TiO}_{2}$ content of phlogopite from the phonotephrites is high ( $\approx 10 \mathrm{wt} \%)$. Leucite occurs as microphenocrysts, except in the Gradishte UK latites. This phase is sometimes partially or totally replaced by analcime, zeolites and clay minerals.

The groundmass consists of the same minerals occurring as phenocrysts with the addition of feldspars, represented by $\mathrm{Na}$-sanidine and oligoclase. Sanidine locally displays a poikilitic texture and has $\mathrm{BaO}$ contents of up to $\approx 5 \mathrm{wt} \%$ (Mlado Nagorichane). In Jezevo Brdo, Mlado Nagorichane and Kishino, there are patches of calcite with $\mathrm{MgCO}_{3}$ contents of around 5-7 mole \%.

Table 2 summarizes the main petrographical and chemical features of the studied rocks.

Evidence for the Roman-type affinity of the UK group

The petrogenetic affinity of UK rocks from Macedonia is poorly defined on the basis of chemical parameters alone.
Taking into account the distribution of major elements and, in particular, the $\mathrm{CaO} / \mathrm{MgO}$ ratio, these rocks are intermediate between those of the Group III (Roman Province type) and Group I (lamproites) of Foley et al. (1987; see also Prelević et al. 2005; 2007). However, based on the relatively high $\mathrm{Al}_{2} \mathrm{O}_{3}$ content, the molar $\mathrm{K}_{2} \mathrm{O} / \mathrm{Al}_{2} \mathrm{O}_{3}<0.8$ and La content $<130$ ppm (see below and Table 1), these rocks are collectively considered to have a Roman-type affinity. Their mineralogical composition further supports this petrogenetic attribution. In particular, the conspicuous presence of sodic plagioclase in some lavas (i.e. Jezevo Brdo), Fe-poor sanidine $\left(\mathrm{Fe}_{2} \mathrm{O}_{3}<0.8 \mathrm{wt} \%\right)$ and leucite $\left(\mathrm{Fe}_{2} \mathrm{O}_{3}<1 \mathrm{wt} \%\right)$ together with relatively Al-rich clinopyroxene (typically $\mathrm{Al}_{2} \mathrm{O}_{3}>1 \mathrm{wt} \%$ ) is noteworthy. Lastly, the high $\mathrm{Al}_{2} \mathrm{O}_{3}$ content $(>12 \mathrm{wt} \%)$ of phlogopite, a typical primary phase of UK Macedonian rocks, distinguishes these rocks from the lamproite phlogopites (Fig. 6).

Pressure and temperature estimate

Crystallization temperatures were assessed on the basis of the partitioning of $\mathrm{Fe}$ and $\mathrm{Mg}$ between olivine and the whole rock using the geothermometer of Beattie( 1993) and Putirka et al. (2007). Crystallization pressures were determined using the thermobarometer of Putirka et al. (2003), which yields T and $\mathrm{P}$ estimates for clinopyroxene in equilibrium with coexisting
Fig. $7 \mathrm{Ni}$ (a) and $\mathrm{Cr}$ (b) concentrations (ppm) vs $\mathrm{MgO}$ (wt\%). Symbols as in Fig. 3
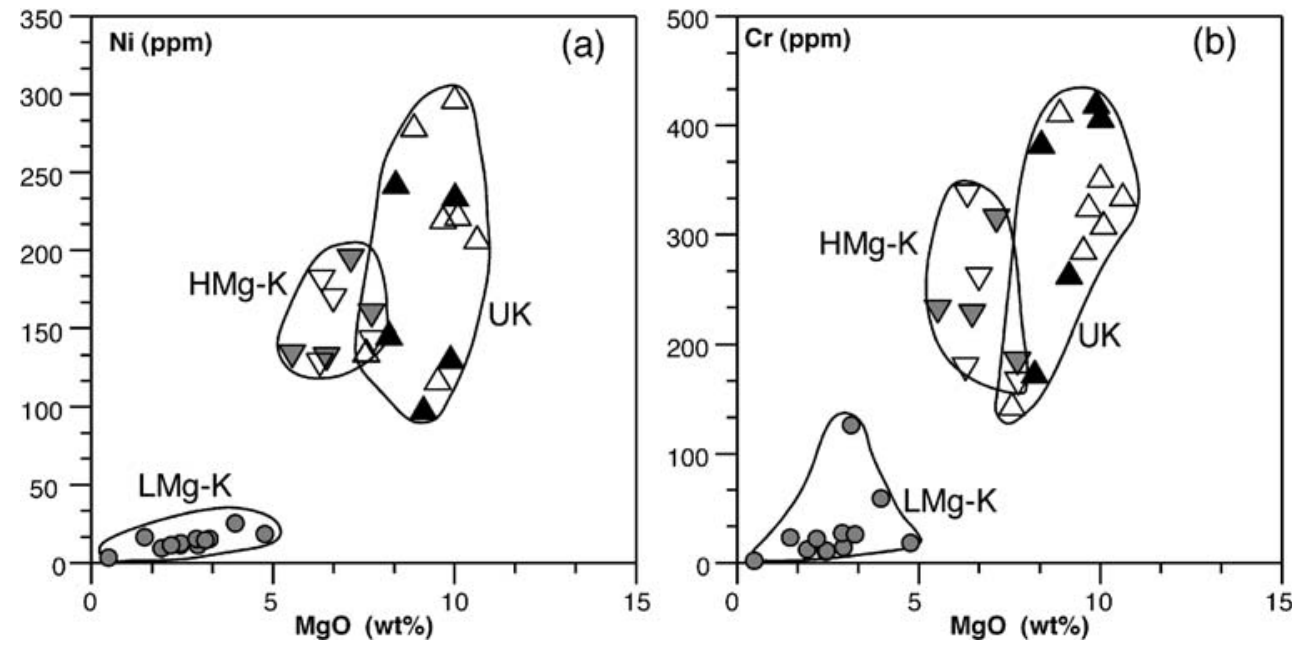
liquid. Results are reported in Table 3. The crystallization temperature of mafic phenocrysts in the UK group ranges between 1,300 and $1,250^{\circ} \mathrm{C}$. The lowest $\mathrm{T}$ was calculated for the latite of Djurishte (about $1,200^{\circ} \mathrm{C}$ ). The clinopyroxene segregation pressure of 1.7 to $0.7 \mathrm{GPa}$ corresponds to depths well within the lithospheric mantle.
$\mathrm{K}-\mathrm{Ar}$ ages

Table 4 reports six new $\mathrm{K}-\mathrm{Ar}$ age determinations for UK and $\mathrm{HMg}-\mathrm{K}$ rocks from Macedonia; they range between 3.24 Ma (Jezevo Brdo) and 1.47 Ma (Kishino; Fig. 2). Our data enlarge the existing data set for the younger magmatic
Fig. 8 Primordial mantlenormalized incompatible element and CI chondritenormalized REE patterns (McDonough and Sun 1995). a and b LMg-K Group; c and d, $\mathrm{HMg}-\mathrm{K}$ Group; e and f, UK Group a

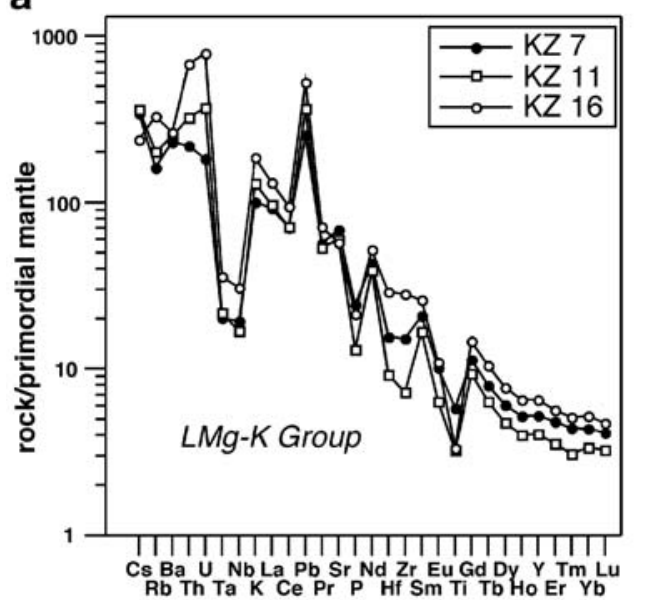

C

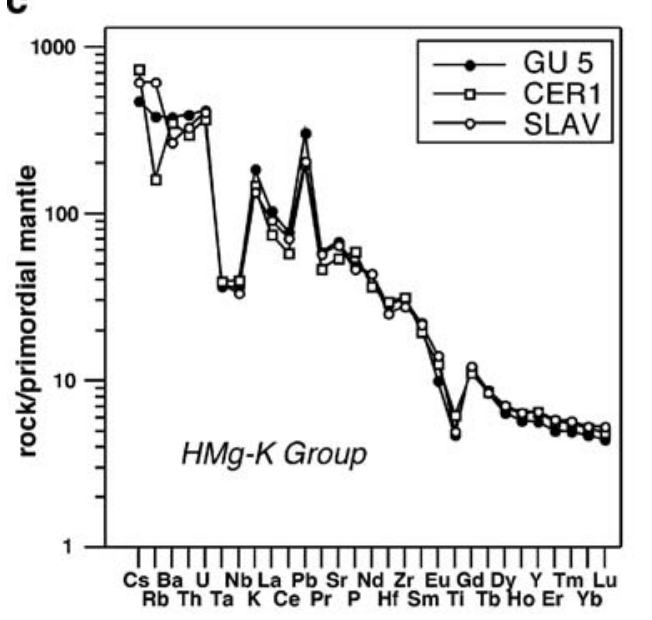

e

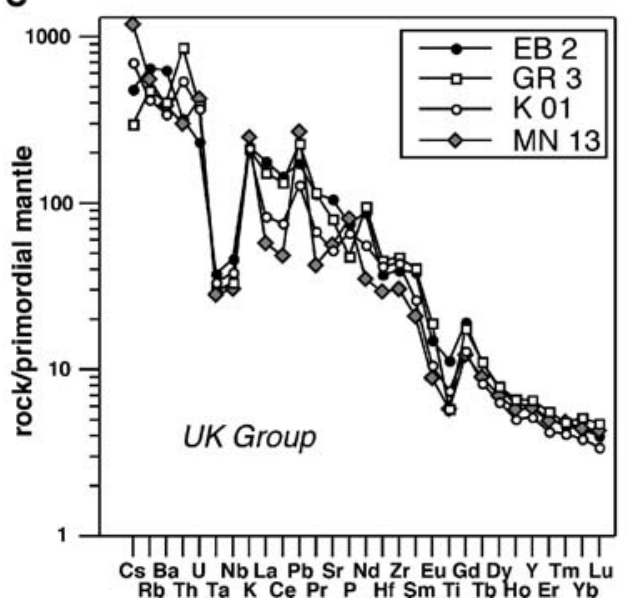

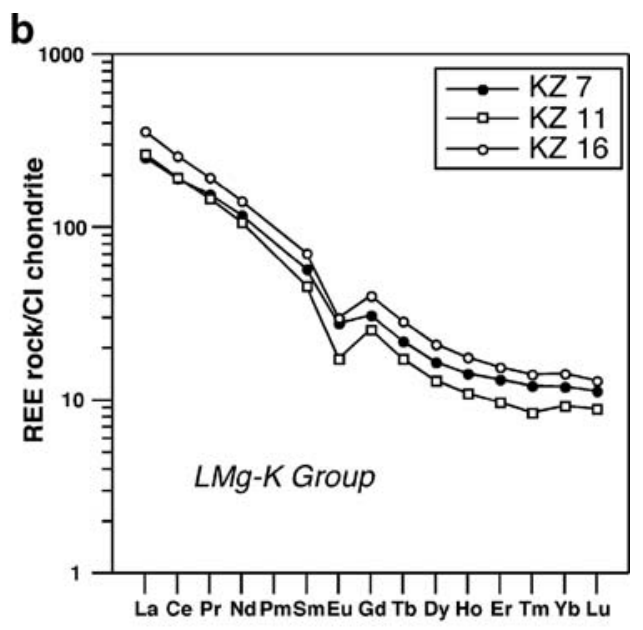

d

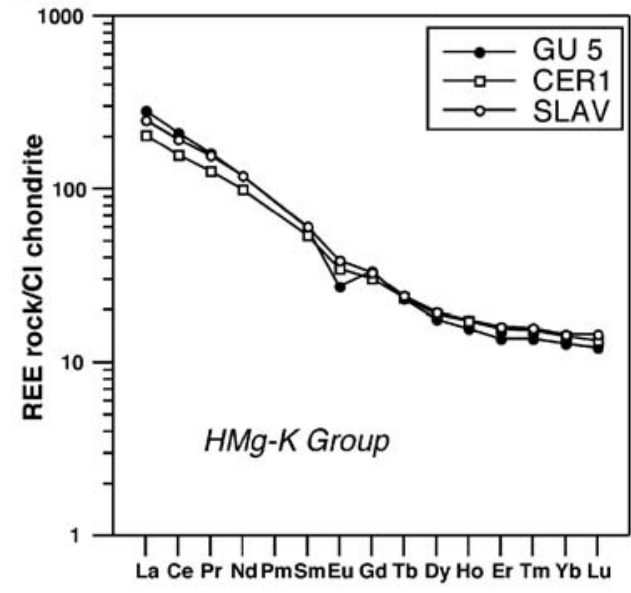

$f$

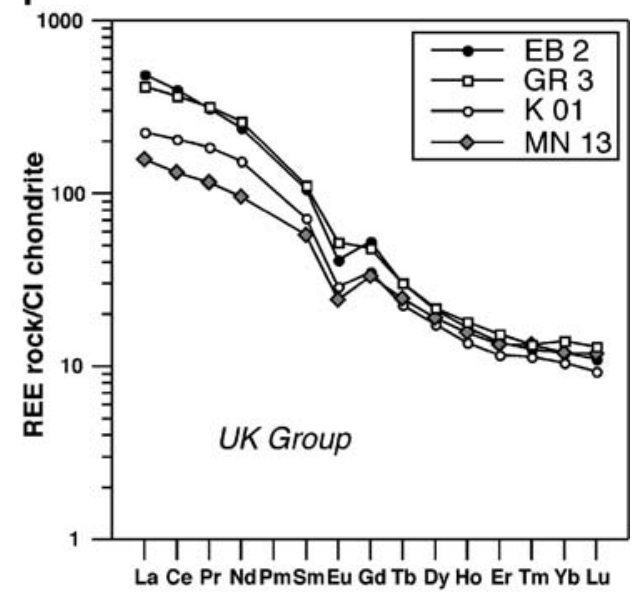




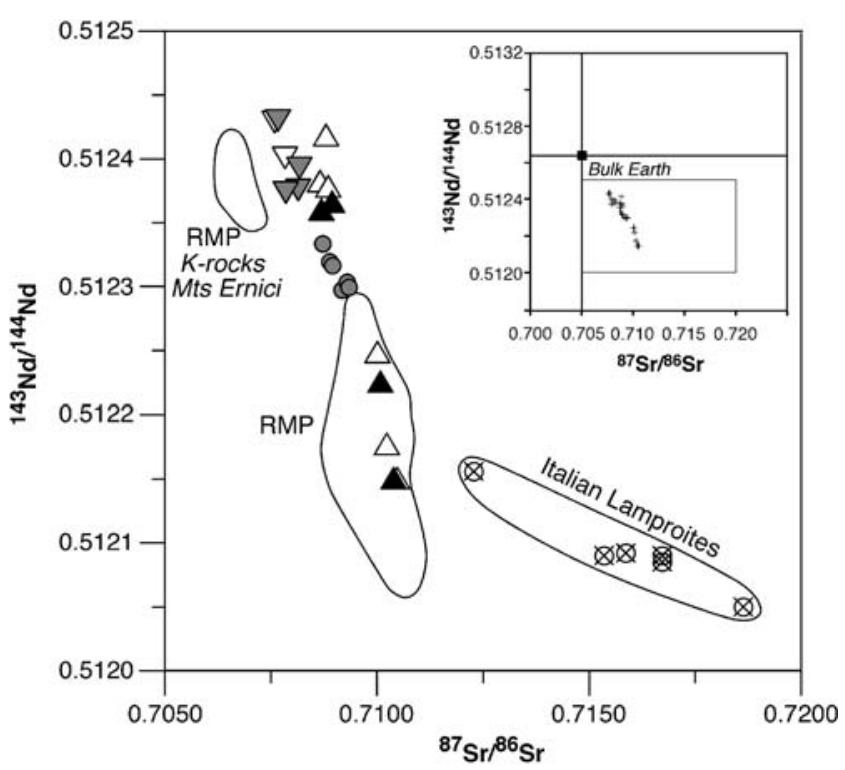

Fig. $9{ }^{143} \mathrm{Nd} /{ }^{144} \mathrm{Nd} v \mathrm{vs}{ }^{87} \mathrm{Sr} /{ }^{86} \mathrm{Sr}$ plot for the studied samples. The data for the Roman Magmatic Province (RMP; Conticelli et al. 2002) and for the Tuscan lamproites (Conticelli et al. 2002; Peccerillo and Martinotti 2006) are also plotted for comparison. Symbols as in Fig. 3

products occurring in the Vardar Zone, south of the ScutariPeć fault zone. Moreover, the new determinations modify the K-Ar ages reported by Terzić and Svešnikova (1991) of 9.5 Ma for the lava of Kureshnichka Krasta and of 5.5 Ma for that of Jezevo Brdo, which instead yield Late Pliocene isotopic ages of $2.04 \pm 0.10$ and $3.24 \pm 0.11 \mathrm{Ma}$, respectively. The Djurishte latite yields an age of $3.19 \pm 0.12 \mathrm{Ma}$, whereas the UK rocks have $\mathrm{K}-\mathrm{Ar}$ ages of $1.81 \pm 0.07 \mathrm{Ma}$ at Mlado Nagorichane, $1.70 \pm 0.08 \mathrm{Ma}$ at Gradishte and $1.47 \pm 0.09 \mathrm{Ma}$ at Kishino, respectively. The UK group is thus representative of the youngest magmatic activity in the Macedonia volcanic belt. Older ages were determined for the volcanics from Slavujevci $(6.57 \mathrm{Ma})$ and Cer, in southernmost Serbia $(3.86 \pm 0.17$ Ma, Cvetković et al.
2004), as well as in the Kozuf Massif ( $\approx 6.5 \mathrm{Ma}$, Kolios et al. 1980; Boev and Lepitkova 1991).

\section{Geochemistry}

Major and trace element data are listed in Table 1. The Kozuf samples (LMg-K group) show relatively evolved compositions, as indicated by their low $\mathrm{Mg} \#$ and low $\mathrm{MgO}$, $\mathrm{Ni}$ and $\mathrm{Cr}$ concentrations (Fig. 7). They show good negative correlations between $\mathrm{SiO}_{2}$ and $\mathrm{TiO}_{2}, \mathrm{Fe}_{2} \mathrm{O}_{3}$, $\mathrm{MgO}, \mathrm{CaO}$ and $\mathrm{P}_{2} \mathrm{O}_{5}$, whereas $\mathrm{Al}_{2} \mathrm{O}_{3}, \mathrm{Na}_{2} \mathrm{O}$ and $\mathrm{K}_{2} \mathrm{O}$ show scattered values. Overall, major element variations are consistent with a fractional crystallization process mainly involving the mafic phases. However, the spread of data, mostly alkali and alumina contents, implies the occurrence of other concomitant processes.

The HMg-K group is characterized by relatively high $\mathrm{MgO}$ (5.3-7.6 wt\%), $\mathrm{Ni}$ and $\mathrm{Cr}$ (194-131 and 314$180 \mathrm{ppm}$, respectively); however, these elements are not correlated with $\mathrm{MgO}$ (Fig. 7). $\mathrm{SiO}_{2}$ varies from 51.6 to $55.8 \mathrm{wt} \%$ and shows no significant correlation with other major or trace elements.

Rocks belonging to the UK group have primitive compositions with high $\mathrm{MgO}$ (6.9 to $9.9 \mathrm{wt} \%$ ) and $\mathrm{Cr}$ and Ni contents (243-100 and 420-170 ppm, respectively); the decrease in $\mathrm{MgO}$ is not coupled with a decrease of compatible elements (Fig. 7). Overall, the UK rocks show high dispersion in the Harker diagrams. $\mathrm{SiO}_{2}$ contents range from 46 to $54 \mathrm{wt} \%$ and are significantly lower than those measured in other UK Mediterranean rocks (see Altherr et al. 2004). Note that the $\mathrm{TiO}_{2}$ contents of UK rocks range from 1.5 to $1.1 \mathrm{wt} \%$, whereas those in Jezevo Brdo are significantly higher, ranging from 2.3 to $2.5 \mathrm{wt} \%$.

Figure 8 reports the primordial mantle-normalized incompatible element and chondrite-normalized rare earth element (REE) patterns for selected $\mathrm{LMg}-\mathrm{K}, \mathrm{HMg}-\mathrm{K}$ and UK rocks. All the investigated samples show arc-type
Fig. $10 \mathrm{MgO}(\mathrm{wt} \%) \mathrm{vs}{ }^{87} \mathrm{Sr} /{ }^{86} \mathrm{Sr}$ (a), and $\mathrm{MgO}$ ( $\mathrm{wt} \%$ ) vs ${ }^{143} \mathrm{Nd} /{ }^{144} \mathrm{Nd}$ (b). Symbols as in Fig. 3
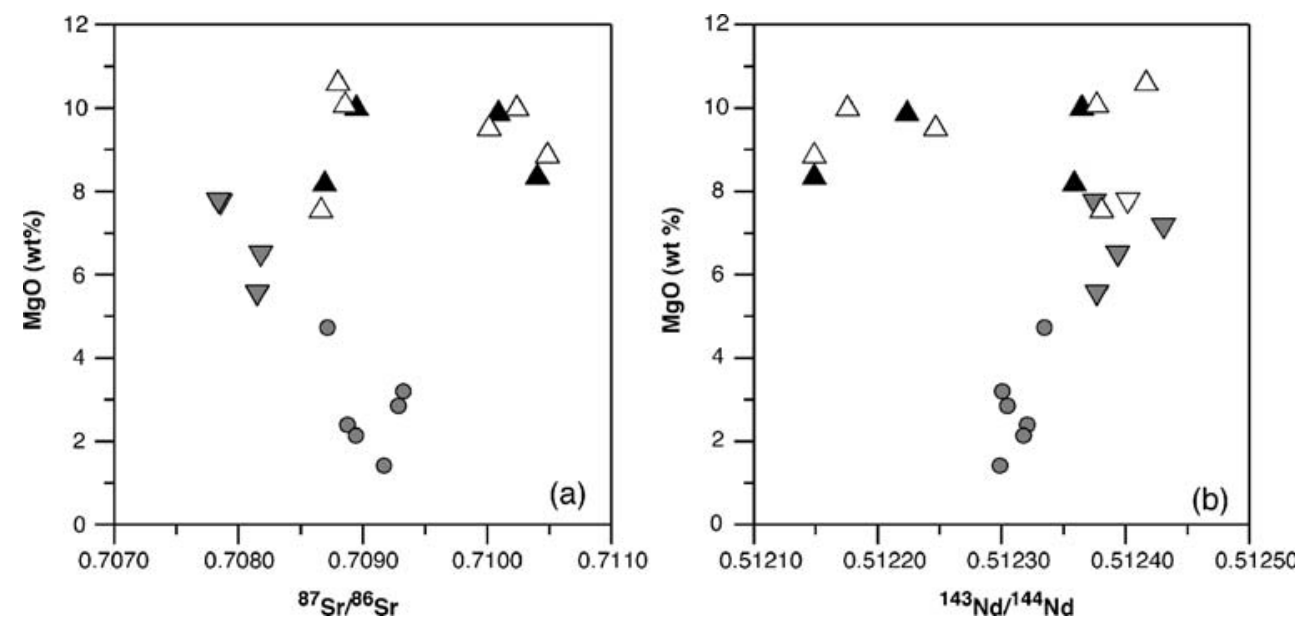


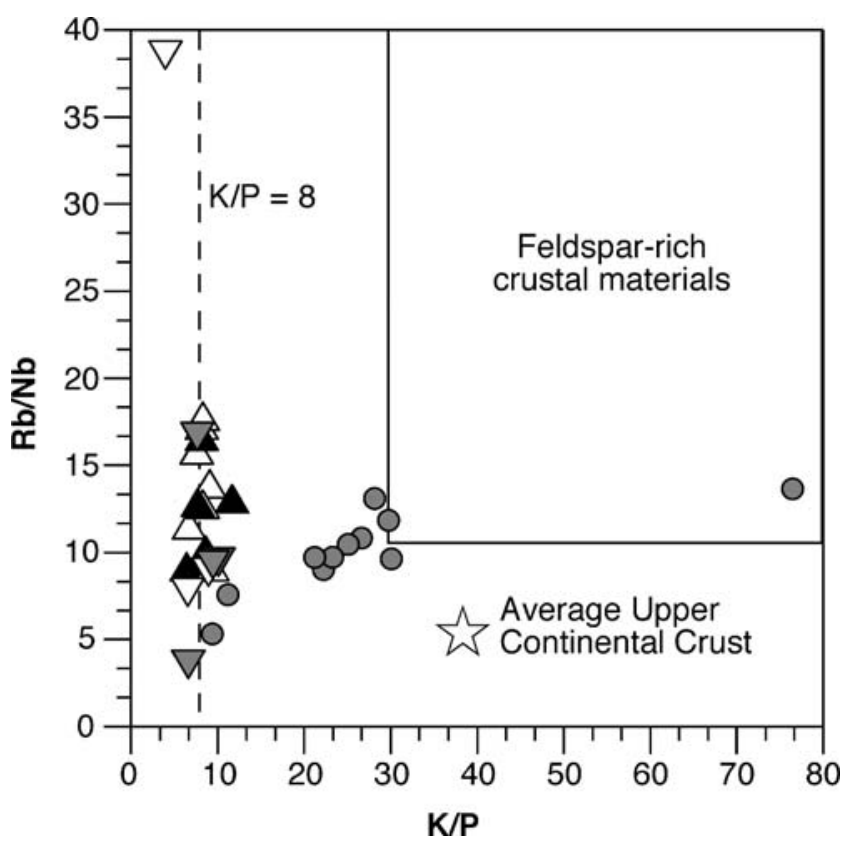

Fig. $11 \mathrm{Rb} / \mathrm{Nb}$ vs $\mathrm{K} / \mathrm{P}$ plot for studied samples. The diagram also shows the field of evolved feldspathic rocks and the average value of the upper continental crust (Taylor and McLennan 1995). $\mathrm{K} / \mathrm{P}=8$ is the average value of $\mathrm{HMg}-\mathrm{K}$ and $\mathrm{UK}$ rocks (excluding $\mathrm{LMg}-\mathrm{K}$ samples). Symbols as in Fig. 3

incompatible element distributions; they are generally enriched in LILE, with high LILE/HFSE ratios and typical negative $\mathrm{Ta}, \mathrm{Nb}$ and $\mathrm{Ti}$ anomalies, along with a positive $\mathrm{Pb}$ spike which decreases from the LMg-K samples to the UK rocks. Moreover, the $\mathrm{LMg}-\mathrm{K}$ samples are characterized by positive $\mathrm{Th}$ and $\mathrm{U}$ spikes and negative $\mathrm{Hf}$ and $\mathrm{Zr}$ anomalies. These anomalies are reduced in the $\mathrm{HMg}-\mathrm{K}$ rocks and almost absent in the UK rocks. In contrast to other UK Mediterranean rocks, no negative $\mathrm{Ba}$ anomaly was observed (Altherr et al. 2004).

The REE patterns show a pronounced and variable enrichment of LREE over HREE, with $\mathrm{La}_{\mathrm{N}} / \mathrm{Yb}_{\mathrm{N}}$ ranging from 13 (UK rocks from Mlado Nagorichane) to 42 (LMg$\mathrm{K}$ group). The LREE display different degrees of fractionation; the highest degree of fractionation is observed in the $\mathrm{LMg}-\mathrm{K}$ rocks $\left(\mathrm{La}_{\mathrm{N}} / \mathrm{Sm}_{\mathrm{N}}\right.$ from 2.6 to 7.7$)$ and the lowest in the UK group $\left(\mathrm{La}_{N} / \mathrm{Sm}_{\mathrm{N}}\right.$ from 2.7 to 4.6). Note that the UK rocks show convex-upward LREE patterns, which become more pronounced in the most La-enriched samples (Fig. 8). Very similar REE patterns are found among the CircumMediterranean ultrapotassic rocks, such as in southeastern Spain (Venturelli et al. 1984a), Tuscany (Peccerillo 2005), northwestern Alps (Venturelli et al. 1984b) and Serbia (Prelević et al. 2005). Convex-upward LREE patterns may be obtained through the metasomatic enrichment of a strongly LREE depleted mantle source.

Heavy REE show the same degree of fractionation in $\mathrm{LMg}-\mathrm{K}$ rocks $\left(\mathrm{Tb}_{\mathrm{N}} / \mathrm{Yb}_{\mathrm{N}}\right.$ from 1.7 to 1.9$)$, whereas they show variable and greater degrees of fractionation in $\mathrm{HMg}$ -
$\mathrm{K}$ and UK lavas $\left(\mathrm{Tb}_{\mathrm{N}} / \mathrm{Yb}_{\mathrm{N}}\right.$ from 1.3 and 2.5). Overall, the slight U-shape of HREE patterns becomes more pronounced from $\mathrm{LMg}-\mathrm{K}$ to $\mathrm{UK}$ rocks. The negative $\mathrm{Eu}$ anomaly is ubiquitous, even in the UK rocks showing no evidence for early plagioclase crystallization.

The investigated rocks are characterized by relatively high ${ }^{87} \mathrm{Sr} /{ }^{86} \mathrm{Sr}$ and low ${ }^{143} \mathrm{Nd} /{ }^{144} \mathrm{Nd}$ ratios (Table 1) and fall in the enriched quadrant of the $\mathrm{Sr}-\mathrm{Nd}$ isotopic diagram (Fig. 9). $\mathrm{Sr}$ and $\mathrm{Nd}$ isotope variability is quite large and comparable to that observed by Altherr et al. (2004). With respect to $\mathrm{K}$ and UK rocks from other Mediterranean occurrences (e.g. SW Spain, Central Italy, Sisco), these rocks are characterized by lower ${ }^{87} \mathrm{Sr} /{ }^{86} \mathrm{Sr}$ and higher ${ }^{143} \mathrm{Nd} /{ }^{144} \mathrm{Nd}$ ratios. The $\mathrm{HMg}-\mathrm{K}$ rocks $\left({ }^{87} \mathrm{Sr} /{ }^{86} \mathrm{Sr}=\right.$ $0.70768-0.70818$ and ${ }^{143} \mathrm{Nd} /{ }^{144} \mathrm{Nd}=0.51243-0.51238$ ) show the highest $\mathrm{Nd}$ and lowest $\mathrm{Sr}$ isotope ratios. The LMg-K group varies in a narrow range $\left({ }^{87} \mathrm{Sr} /{ }^{86} \mathrm{Sr}=0.7087\right.$ 0.7093 and ${ }^{143} \mathrm{Nd} /{ }^{144} \mathrm{Nd}=0.51233-0.51229$ ), whereas the UK rocks display large isotope variations $\left({ }^{87} \mathrm{Sr} /{ }^{86} \mathrm{Sr}=\right.$ $0.70869-0.7104$ and $\left.{ }^{143} \mathrm{Nd} /{ }^{144} \mathrm{Nd}=0.51237-0.51215\right)$, with a negative correlation between $\mathrm{Sr}$ and $\mathrm{Nd}$.

\section{Discussion}

\section{Role of low pressure processes}

The formation of the Tertiary and Quaternary Balkan UK and $\mathrm{K}$ province has been ascribed to partial melting of a mantle metasomatized by subducted components during the Mesozoic (Altherr et al. 2004; Boev and Yanev 2001; Yanev et al. 2003 for Macedonian lavas; Prelević et al. 2001; 2005; 2007; Cvetković et al. 2004 for Serbian lavas). Low pressure processes such as fractional crystallization and/or interaction with the continental crust have also been proposed to explain several geochemical features and, in particular, the large range of isotopic variations. The $\mathrm{Sr}$ and $\mathrm{Nd}$ isotope ratios of the studied rocks with respect to $\mathrm{MgO}$ contents are reported in Fig. 10. The most primitive samples, represented by UK group $(\mathrm{MgO}>8 \mathrm{wt} \%)$, almost span the whole range of ${ }^{143} \mathrm{Nd} /{ }^{144} \mathrm{Nd}$ and ${ }^{87} \mathrm{Sr} /{ }^{86} \mathrm{Sr}$ values and show no significant correlation with $\mathrm{MgO}$ contents. This suggests that fractional crystallization accompanied by crustal assimilation cannot explain the observed variations in UK rocks. In contrast, the $\mathrm{LMg}-\mathrm{K}$ volcanics show relatively small variations in both $\mathrm{Sr}$ and $\mathrm{Nd}$ isotope ratios with a significant decrease in $\mathrm{MgO}$ contents. This is consistent with the occurrence of fractional crystallization processes, probably combined with low degrees of crustal assimilation. The HMg-K group displays relatively small isotope variability; however, the data points are well correlated with $\mathrm{MgO}$ and define a trend line which extends that defined by the LMg-K samples. To better highlight the 
interaction of magmas with crustal materials, we plotted data in the $\mathrm{K} / \mathrm{P}$ vs $\mathrm{Rb} / \mathrm{Nb}$ diagram (Fig. 11 ), being $\mathrm{K} / \mathrm{P}$ and $\mathrm{Rb} / \mathrm{Nb}$ elemental ratios very sensitive to the upper crustal contamination. The LMg-K samples clearly point towards evolved feldspathic crustal materials, whereas the HMg-K and UK rocks show a strong increase in the $\mathrm{Rb} / \mathrm{Nb}$ ratio at an almost constant $\mathrm{K} / \mathrm{P}$ ratio (about 8 , i.e. very close to the average value of mantle-derived basalts). Geochemical signatures thus suggest that these rocks were affected by a fractional crystallization process associated with crustal contamination. The most primitive LMg-K lavas display geochemical characteristics very similar to those of $\mathrm{HMg}-\mathrm{K}$ group cropping out in the investigated area. The relatively small $\mathrm{Sr}$ and $\mathrm{Nd}$ isotope variations are explained by the buffering effect of the high $\mathrm{Sr}$ and $\mathrm{Nd}$ contents of the analyzed samples (1,100-1,300 ppm Sr and 35-60 ppm Nd, considerably higher than the average upper continental crust).

In conclusion, the collected geochemical data indicate that rocks from the $\mathrm{LMg}-\mathrm{K}$ group were significantly affected by crustal contamination, whereas the $\mathrm{HMg}-\mathrm{K}$ and UK rocks were not; we therefore believe that geochemical features of the latter rocks reflect mantle heterogeneity, as also suggested by Prelević et al. (2005) and Prelević and Foley (2007).

Geochemical evolution of the source region

The UK rocks have a large isotope variability which is not correlated with the emplacement age, the geographic position or, as mentioned earlier, the $\mathrm{MgO}$ contents (Fig. 10). The low $\mathrm{Al}_{2} \mathrm{O}_{3}$ contents, the relatively low $\mathrm{CaO} / \mathrm{Al}_{2} \mathrm{O}_{3}$ ratios (average of 0.57 ), and the refractory nature of some minerals such as olivine and spinel (Prelević et al. 2005) are consistent with a residual mantle source (Cvetković et al. 2007). P and T estimates (Table 3) are also consistent with a lithospheric mantle source. However, the enrichment in LILE, the radiogenic Sr and non-radiogenic $\mathrm{Nd}$ of this source suggest that it has been modified by a metasomatic event (Yanev et al. 2003; Altherr et al. 2004; Prelević et al. 2005; 2007). In the $\mathrm{Zr} / \mathrm{Nb}$ vs ${ }^{143} \mathrm{Nd} /{ }^{144} \mathrm{Nd}$
Fig. $12{ }^{143} \mathrm{Nd} /{ }^{144} \mathrm{Nd}$ vs $\mathrm{Zr} / \mathrm{Nb}$ (a), Th/Ta (b), $\mathrm{Pb} / \mathrm{Ce}(\mathbf{c})$, and $\mathrm{Pb} / \mathrm{Th}$ (d). MORB values from Niu and O'Hara (2003). Symbols as in Fig. 3
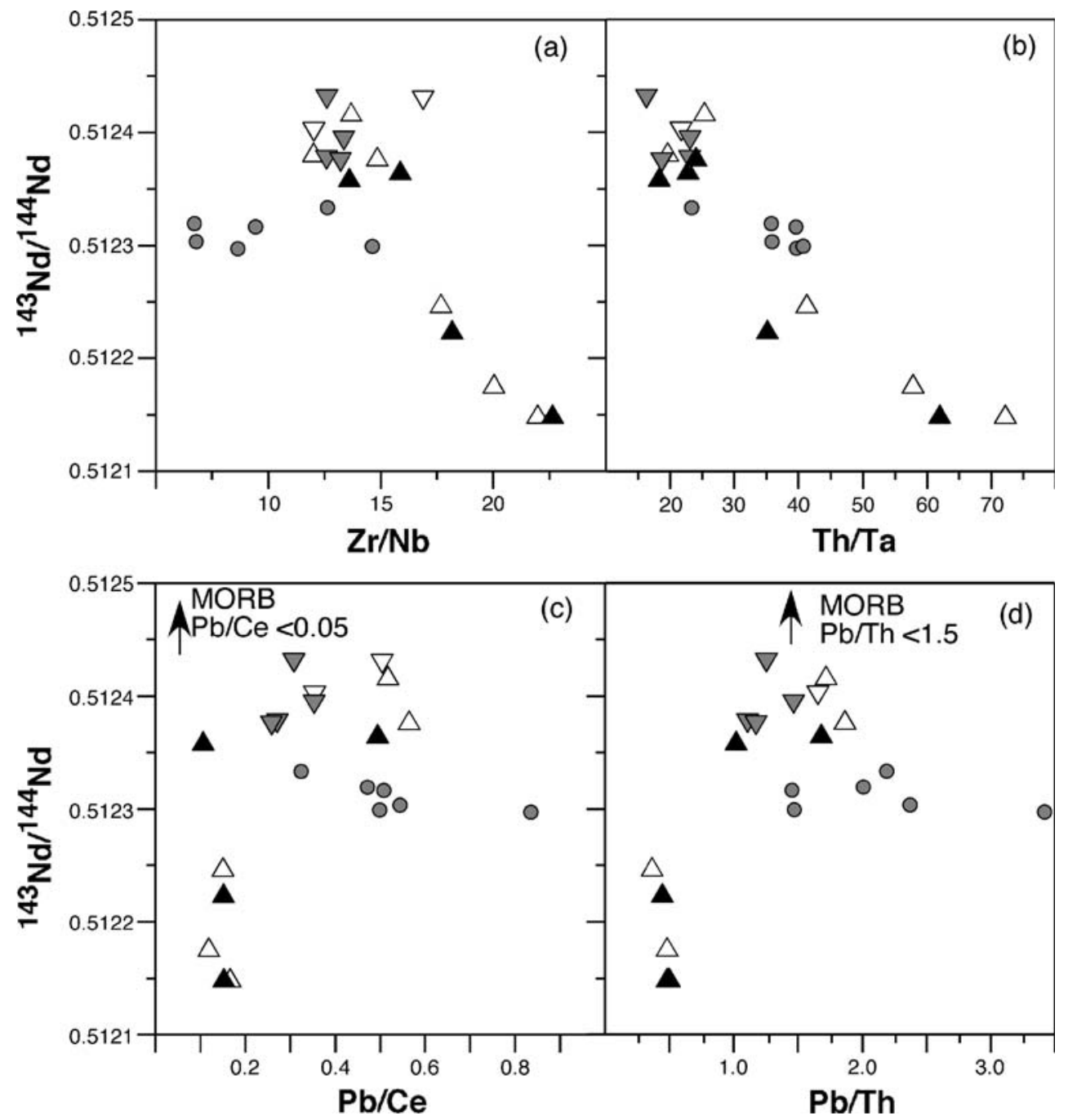
diagram (Fig. 12a), the UK rocks show a negative correlation: samples with the highest $\mathrm{Zr} / \mathrm{Nb}$ ratios have the lowest $\mathrm{Nd}$ ratios, whereas both $\mathrm{UK}$ and $\mathrm{HMg}-\mathrm{K}$ group fall in a field characterized by high $\mathrm{Nd}$ isotope ratios and small variations in the $\mathrm{Zr} / \mathrm{Nb}$ ratio. An analogous trend is observed in the ${ }^{143} \mathrm{Nd} /{ }^{144} \mathrm{Nd}$ versus $\mathrm{Th} / \mathrm{Ta}$ diagram (Fig. 12b). The similar behavior of the $\mathrm{Zr} / \mathrm{Nb}$ and $\mathrm{Th} / \mathrm{Ta}$ ratios suggests that the enrichment of $\mathrm{Zr}$ and $\mathrm{Th}$, coupled with the low ${ }^{143} \mathrm{Nd} /{ }^{144} \mathrm{Nd}$ and high ${ }^{87} \mathrm{Sr} /{ }^{86} \mathrm{Sr}$ ratios, is linked to metasomatism of a mantle domain by an agent having a crustal affinity. The nature of this agent can be investigated considering the relative enrichment of fluidmobile elements $(\mathrm{Cs}$ and $\mathrm{Pb})$ with respect to relatively fluid-immobile elements ( $\mathrm{Zr}$ and Th). In the ${ }^{143} \mathrm{Nd} /{ }^{144} \mathrm{Nd}$ versus $\mathrm{Pb} / \mathrm{Ce}$ and $\mathrm{Pb} / \mathrm{Th}$ diagram (Fig. 12c and d) all the studied samples are relatively depleted in $\mathrm{Pb}$ (and $\mathrm{Cs}$, not shown) with respect to Ce and Th (and Zr not shown); the UK latites and shoshonites of the Kureshnichka Krasta and Gradishte are strongly depleted in $\mathrm{Pb}$ (and $\mathrm{Cs}$ ), with $\mathrm{Pb} / \mathrm{Th}$ ratios lower that those of average MORB and $\mathrm{Pb} / \mathrm{Ce}$ ratios close to MORB values (Niu and O'Hara 2003). These features suggest that the metasomatized component was essentially a melt rather than a fluid. Note that the UK rocks from Mlado Nagorichane and Jezevo Brdo (phonotephrites, Table 1 and Fig. 12), along with the HMg-K group, define a subset with a relatively homogeneous geochemical imprint. We tentatively interpret these lavas as derived from a mantle domain in which the metasomatized component played a minor role with respect to the source region that fed the volcanism of Kureshnichka Krasta and Gradishte.

\section{Geodynamic implications}

The geochemical features of the investigated $\mathrm{HMg}-\mathrm{K}$ to UK rocks suggest that they originated from a refractory lithospheric mantle (see also Cvetković et al. 2007) metasomatized by an agent essentially consisting of silicate melts derived from a subducted component already depleted in fluids. This implies that the metasomatic episode occurred during a waning phase of the subduction process. The activation of a relatively shallow lithospheric source is linked to the extensional process affecting the region at least since the Oligocene.

Volcanic activity (Fig. 13) was probably the result of three concomitant processes: (1) Dinaric subduction and extension, active since at least the Paleogene (Dumurdzanov et al. 2005); (2) the northwestern extension of the Aegean Sea rift; and (3) the southern termination of Pannonian Basin rifting in the hanging wall of the eastward retreating Carpathian subduction zone. The rifting episodes led to the collapse and stretching of the thickened lithosphere, allowing the uplift of the previously metasomatized underlying mantle. This opposite movement created favorable conditions for the

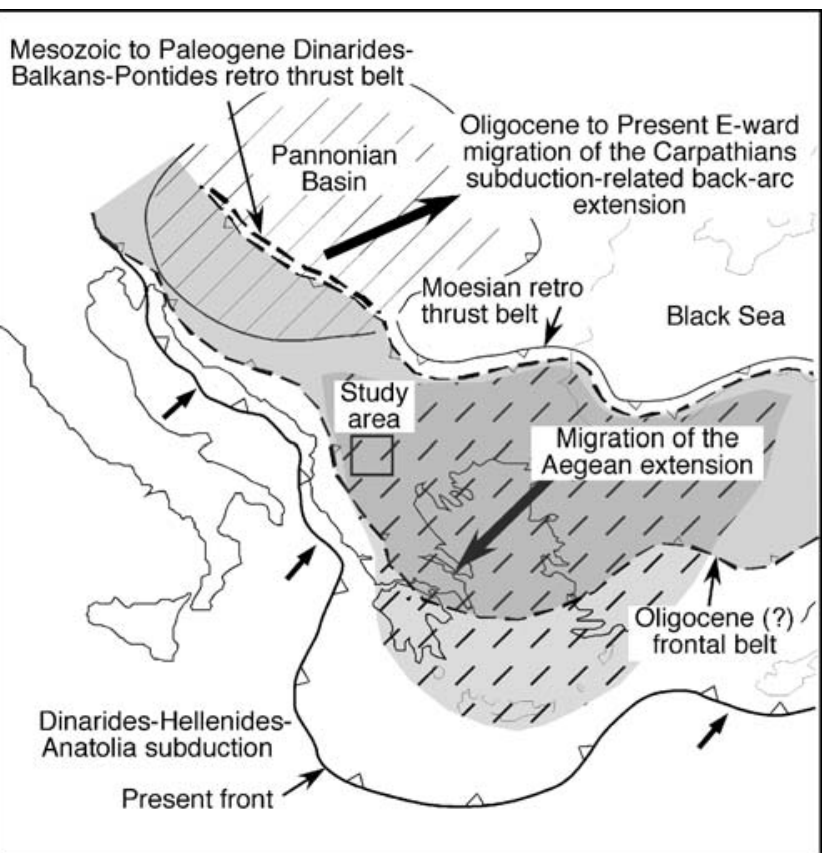

Fig. 13 Sketch map showing the geodynamic setting of the AegeanBalkanic region. The study area (box) is located in the hangingwall of the Mesozoic to present-day Dinaric subduction (small black arrows), which underwent widespread late and syn-subduction Cenozoic extension associated with the Aegean rift and, to the north, with the Pannonian rift. The origin of the HMg-K und UK volcanic rocks of Macedonia is consistent with a subduction setting and coeval extensional tectonics

generation of ultrapotassic to potassic magmas, firstly (Oligocene-Early Miocene) in central Serbia and lately (Late Miocene to Pleistocene) in southernmost Serbia and Macedonia. We believe that this subduction is the Late Cretaceous northeastward subduction of the Western Vardar Ocean, with the Apulian plate under the edge of the Eurasian one (Carminati et al. 2004). The remnants of the subducted Apulian plate are visible on tomographic profiles (Piromallo and Morelli 2003; Bennet et al. 2008). Magmatism possibly ceased due to a decrease in the subduction rate caused by the docking of the thicker Adriatic-Apulian lithosphere at the Dinaric subduction trench.

\section{Summary and conclusions}

In Macedonia, Late Miocene to Pleistocene potassic and ultrapotassic volcanic rocks are exposed in the Vardar zone, from south of Scutari-Peć fault zone to the Greek border. The erupted products show a subduction-related signature (enrichment in LILE, high LILE/HFSE ratios and typical negative $\mathrm{Ta}, \mathrm{Nb}$ and $\mathrm{Ti}$ anomalies) but variable potassiumenrichment and petrogenetic affinity. Three main rock groups have been identified: the first two groups display shoshonitic features and are represented by: (1) $\mathrm{LMg}-\mathrm{K}$ 
rocks forming the Kozuf Massif which extends also in Greece and (2) HMg-K scattered small volcanic centers extending from the Serbia-Macedonia border to central Macedonia, which are silica saturated or slightly undersaturated lavas with more alkaline and K-rich character. The last group is formed by ultrapotassic, primitive, frequently leucite-bearing lavas, which represent the youngest volcanism of the area and range in age from 1.8 to $1.5 \mathrm{Ma}$. Based on chemical and mineralogical composition these rocks are inferred to have a petrogenetic affinity akin to the Group III (Roman Province type) ultrapotassic rocks of Foley et al. (1987). All the studied rocks are characterized by relatively high ${ }^{87} \mathrm{Sr} /{ }^{86} \mathrm{Sr}$ and low ${ }^{143} \mathrm{Nd} /{ }^{144} \mathrm{Nd}$ ratios and fall in the enriched quadrant of the $\mathrm{Sr}-\mathrm{Nd}$ isotopic diagram. Isotopic and geochemical data reveal that $\mathrm{LMg}-\mathrm{K}$ lavas were affected by upper crustal contamination processes, whereas $\mathrm{HMg}-\mathrm{K}$ and UK groups display variations mainly reflecting geochemical heterogeneity of the mantle source; these rocks are interpreted as the result of partial melting of a refractory source whose geochemical composition was modified by the addition of a metasomatic agent essentially constituted by melts as stressed by the relative depletion of fluid mobile with respect to fluid immobile elements (i.e. $\mathrm{Cs}$ and $\mathrm{Pb}$ versus $\mathrm{Zr}$ and $\mathrm{Th}$ ). The heterogeneous nature of the refractory mantle source as well as geothermometric calculations support the hypothesis that this source was localized in the lithospheric mantle.

The eruption of the HMg-K and UK rocks is related to rifting episodes that occurred in the region since at least the Oligocene. The overall arc-type geochemical signature of the Macedonia Mio-Pleistocene lavas confirms their relation with Dinaric subduction, active since the Late EoceneOligocene. The later stretching of this area is considered the result of two concurrent and coeval processes, the dominant southwestern extension of the Aegean Sea rift and, to the north, the Pannonian rifting due to the retreat of the Carpathian subduction zone.

Acknowledgments This research was financially supported by PRIN (Cofin-MIUR) and by CNR grants. We thank Dejan Prelevic and Hilary Downes for their constructive reviews; the editorial handling of Johann Raith was greatly appreciated.

\section{References}

Agostini S, Doglioni C, Innocenti F, Manetti P, Tonarini S, Savasçin MY (2007) The transition from subduction-related to intraplate Neogene magmatism in the Western Anatolia and Aegean area. In: Beccaluva L, Bianchini G, Wilson M (eds) Cenozoic volcanism in the Mediterranean area. Geol Soc Am Spec Paper 418:1-15

Altherr R, Meyer H-P, Holl A, Volker F, Alibert C, McCulloch MT, Majer V (2004) Geochemical and $\mathrm{Sr}-\mathrm{Nd}-\mathrm{Pb}$ isotopic character- istics of Late Cenozoic leucite lamproites from the East European Alpine belt (Macedonia and Yugoslavia). Contrib Mineral Petrol 147:58-73

Battaglia M, Murray MH, Serpelloni E, Bürgmann R (2004) The Adriatic region: An independent microplate within the AfricaEurasia collision zone. Geophys Res Lett 31:L09605

Beattie P (1993) Olivine-melt and orthopyroxene-melt equilibria. Contrib Mineral Petrol 115:103-111

Bennet RA, Hreinsdóttir S, Buble G, Basić T, Bacić Z, Marjanovic M, Casale G, Gendaszek A, Cowan D (2008) Eocene to present subduction of southern Adria mantle lithosphere beneath the Dinarides. Geology 36:3-6

Boccaletti M, Manetti P, Peccerillo A (1974) Hypothesis on the plate tectonic evolution of the Carpatho-Balkan arcs. Earth Planet Sci Lett 23:193-198

Boev B, Lepitkova S (1991) Petrologic features of the volcanic rocks from the vicinity of Alshar. Geol Maced 5:15-30

Boev B, Yanev Y (2001) Tertiary magmatism within the Republic of Macedonia: a review. Acta Vulcanol 13:57-72

Carminati E, Doglioni C, Carrara G, Dabovski C, Dumurdjanov N, Gaetani M, Georgiev G, Mauffret A, Sartori R, Seranne M, Scrocca D, Scionti V, Torelli L, Zagorchev I, Argnani A (2004) Transmed: section III. In: Cavazza W, Roure F, Spakman W, Stampfli G, Ziegler P (eds) The Transmed atlas. 32nd IGC Florence, CD-Rom. Springer, Berlin

Conticelli S, D'Antonio M, Pinarelli L, Civetta L (2002) Source contamination and mantle heterogeneity in the genesis of Italian potassic and ultrapotassic rocks: $\mathrm{Sr}-\mathrm{Nd}-\mathrm{Pb}$ isotope data from Roman Province and Southern Tuscany. Mineral Petrol 74:189-222

Cvetković V, Prelević D, Downes H, Jovanović M, Vaselli O, Pécskay Z (2004) Origin and geodynamic significance of Tertiary postcollisional basaltic magmatism in Serbia (central Balkan Peninsula). Lithos 73:161-186

Cvetković V, Downes H, Prelević D, Lazarov M, Resimic-Sarić K (2007) Geodynamic significance of ultramafic xenoliths from eastern Serbia: relics of sub-arc oceanic mantle? J Geodynam 43:504-527

Doglioni C, Busatta C, Bolis G, Marianini L, Zanella M (1996) On the structural evolution of the eastern Balkans (Bulgaria). Mar Pet Geol 13:225-251

Dumurdzanov N, Serafimovski T, Burchfiel BC (2004) Evolution of the Neogene-Pleistocene basins of Macedonia. Geol Soc Am, Digital Map Chart Series 1:1-20

Dumurdzanov N, Serafimovski T, Burchfiel BC (2005) Cenozoic tectonics of Macedonia and its relation to the South Balkan extensional regime. Geosphere 1:1-22

Foley SF, Venturelli G, Green DH, Toscani L (1987) The ultrapotassic rocks: characteristics, classification, and constraints for petrogenetic models. Earth Sci Rev 24:81-134

Harkovska A, Yanev Y, Marchev P (1989) General features of the Paleogene orogenic magmatism in Bulgaria. Geol Balc 19(1):37-72

Irvine TN, Baragar WRA (1971) A guide to the chemical classification of the common volcanic rocks. Can J Earth Sci 8:523-548

Kissel C, Speranza F, Milićević V (1995) Paleomagnetism of external southern and central Dinarides and northern Albanides: implications for the Cenozoic activity of the Scutari-Peć transverse zone. J Geophys Res 100:14999-15007

Kolios N, Innocenti F, Manetti P, Peccerillo A, Giuliani O (1980) The Pliocene volcanism of the Voras Mts (Central Macedonia, Greece). Bull Volcanol 43:553-568

Kovács I, Csontos L, Szabó C, Bali E, Falus G, Benedek K, Zajacz Z (2007) Paleogene-early Miocene to Quaternary volcanism in the Carpathian Pannonian region: role of subduction, extension and mantle plume. Geol Soc Am Special Pap 418:93-112

Le Maitre RW (1989) A classification of igneous rocks and glossary of terms. Blackwell Scientific Publication, Oxford, p 193 
Le Maitre RW (2002) Igneous rocks - a classification and glossary of terms. Cambridge University Press, Cambridge

McDonough WF, Sun SS (1995) The composition of the Earth. Chem Geol 120:223-253

Niu Y, O'Hara MJ (2003) Origin of ocean island basalts: a new perspective from petrology, geochemistry, and mineral physics considerations. J Geophys Res 108:2209

Pamić J, Gusic I, Jelaska V (1998) Geodynamic evolution of the central Dinarides. Tectonophysics 297:251-268

Peccerillo A (2005) Plio-Quaternary volcanism in Italy: petrology, geochemistry, geodynamics. Springer, Berlin

Peccerillo A, Martinotti G (2006) The Western Mediterranean lamproitic magmatism: origin and geodynamic significance. Terra Nova 18:109-117

Piromallo C, Morelli A (2003) P wave tomography of the mantle under Alpine-Mediterranean area. J Geophys Res 108:20065

Prelević D, Foley SF (2007) Accretion of arc-oceanic lithospheric mantle in the Mediterranean: evidence from extremely high-Mg olivines and Cr-rich spinel inclusions from lamproites. Earth Planet Sci Lett 256:120-135

Prelević D, Foley SF, Cvetković V, Jovanović M, Melzer S (2001) Tertiary ultrapotassic-potassic rocks from Serbia, Yugoslavia. Acta Vulcanol 13:101-115

Prelević D, Foley SF, Romer RL, Cvetković V, Downes H (2005) Tertiary ultrapotassic volcanism in Serbia: constraints on petrogenesis and mantle source characteristics. J Petrol 46:1443-1487

Prelević D, Foley SF, Cvetković V (2007) A review of petrogenesis of Mediterranean Tertiary lamproites: a perspective from the Serbian ultrapotassic province. Geol Soc Am Special Pap 418:113-129
Putirka K, Mikaelian H, Ryerson FJ, Shaw H (2003) New clinopyroxene-liquid thermobarometers for mafic, evolved and volatilebearing lava compositions, with applications to lavas from Tibet and the Snake River Plain, ID. Am Mineral 88:1542-1554

Putirka K, Perfit M, Ryerson FJ, Jackson MG (2007) Ambient and excess mantle temperatures, olivine thermometry and active vs. passive upwelling. Chem Geol 241:177-206

Steiger KH, Jäger E (1977) Subcommission on geochronology: convention on the use of decay constants in geo-and cosmochronology. Earth Planet Sci Lett 36:359-362

Taylor SR, McLennan SM (1995) The geochemical evolution of the continental crust. Rev Geophys 33:241-265

Terzić M, Svešnikova EV (1991) Age of leucite-bearing rocks in Yugoslavia. Comptes Rendus des Séances de la Societé de Géologie Serbe de Géologie pour les années 1987, 1988, 1989:283-287

Venturelli G, Capedri S, Di Battistini G, Crawford AJ, Kogarko LN, Celestini S (1984a) The ultrapotassic rocks from southeastern Spain. Lithos 17:37-54

Venturelli G, Thorpe RS, Dal Piaz GV, Del Moro A, Potts JP (1984b) Petrogenesis of calc-alkaline, shoshonitic and associated ultrapotassic Oligocene volcanic rocks from the northwestern Alps. Contrib Mineral Petrol 86:209-220

Yanev Y (2003) Mantle source of the Paleogene collision-related magmas of the Eastern Rhodopes (Bulgaria) and Western Thrace (Greece): characteristics of the mafic magmatic rocks. N Jahrb Mineral Abh 178:131-151

Yanev Y, Boev B, Doglioni C, Innocenti F, Manetti P, Lepitkova S (2003) Neogene ultrapotassic-potassic volcanic association in the Vardar zone (Macedonia). CR Acad Bulg Sci 56(4):53-58 